\title{
Phase Diagram of Al-Ca-Mg-Si System and Its Application for the Design of Aluminum Alloys with High Magnesium Content
}

\author{
Nikolay A. Belov ${ }^{1}$ (D), Evgenia A. Naumova ${ }^{1}$, Torgom K. Akopyan ${ }^{1,2, *}$ and \\ Vitaliy V. Doroshenko ${ }^{1}$ \\ 1 Department of Metal Forming, National University of Science and Technology MISiS, 4 Leninsky pr., \\ 119049 Moscow, Russia; nikolay-belov@yandex.ru (N.A.B.); jan73@mail.ru (E.A.N.); \\ v.doroshenko@mail.ru (V.V.D.) \\ 2 Institution of Russian Academy of Sciences A.A. Baikov Institute of Metallurgy and Material Science RAS, \\ 49 Leninsky pr., 119991 Moscow, Russia \\ * Correspondence: nemiroffandtor@yandex.ru; Tel.: +7-964-503-9177
}

Received: 28 August 2017; Accepted: 9 October 2017; Published: 13 October 2017

\begin{abstract}
The phase transformations in the Al-Ca-Mg-Si system have been studied using thermodynamic calculations and experimental methods. We show that at $10 \%$ Magnesium $(\mathrm{Mg})$, depending on the concentrations of calcium $(\mathrm{Ca})$ and silicon $(\mathrm{Si})$, the following phases crystallize first (apart from the aluminum (Al) solid solution): $\mathrm{Al}_{4} \mathrm{Ca}, \mathrm{Mg}_{2} \mathrm{Si}$, and $\mathrm{Al}_{2} \mathrm{CaSi}_{2}$. We have found that the major part of the calculated concentration range is covered by the region of the primary crystallization of the $\mathrm{Al}_{2} \mathrm{CaSi}_{2}$ phase. Regardless of the Ca and Si content, the solidification of the aluminum-magnesium alloys ends with the following nonvariant eutectic reaction: $\mathrm{L} \rightarrow(\mathrm{Al})+\mathrm{Al}_{4} \mathrm{Ca}$ $+\mathrm{Mg}_{2} \mathrm{Si}+\mathrm{Al}_{3} \mathrm{Mg}_{2}$. With respect to the temperature and composition of the liquid phase, this reaction is close to the eutectic reaction in the Al-Mg binary system. The addition of $\mathrm{Ca}$ and $\mathrm{Si}$ to the $\mathrm{Al}-10 \%$ $\mathrm{Mg}$ base alloy increases its hardness, reduces its density, and has no negative influence on its corrosion resistance. We have also established that the near-eutectic alloy containing about $3 \% \mathrm{Ca}$ and $1 \% \mathrm{Si}$ has the optimum structure.
\end{abstract}

Keywords: metals and alloys; phase diagrams; phase transitions; microstructure; eutectic; solidification; Al-Ca-Mg-Si system; aluminum-magnesium alloys

\section{Introduction}

Aluminum-magnesium alloys are widely used in various products in the automotive industry, shipbuilding, rocket technology, and other important industries [1,2] due to a successful combination of their properties. In particular, their high plasticity and weldability are combined with low density and high corrosion resistance [3,4]. These alloys are non-heat treatable, but at high magnesium contents (about 10\%, corresponding to the casting alloy 520), due to hardening of the aluminum solid solution (hereafter (Al)), the ultimate tensile stress (UTS) in the as-quenched state (T4) is up to $350 \mathrm{MPa}-400 \mathrm{MPa}[1,3]$.

It is advisable to alloy aluminum-magnesium alloys with silicon, which is included in a number of branded alloys (for example, 512) with a content of 1.5-2\% [1,5-7]. Silicon (Si) maintains a low density (it forms, with magnesium $\left(\mathrm{Mg}\right.$ ), the $\mathrm{Mg}_{2} \mathrm{Si}$ phase, the density of which is only $1.88 \mathrm{~g} / \mathrm{cm}^{3}$ [2]) and high corrosion resistance, while also increasing the hardness and casting properties of the alloy. A large number of works reported alloys based on the $\mathrm{Al}+\mathrm{Mg}_{2} \mathrm{Si}$ eutectic, which have a structure typical of composites [8-13]. 
Another promising eutectic-forming element that can be considered a component for aluminum alloys is calcium. With respect to the content in the Earth's core (3.6 wt \%), calcium (Ca) occupies the third place among the metals, yielding only to aluminum and iron. Its density is $1.542 \mathrm{~g} / \mathrm{cm}^{3}$, and as a result, its inclusion reduces the weight of aluminum alloys. In recent years, many publications have considered calcium as a component in magnesium-based alloys [14-24]. However, this element has not yet found a proper application in aluminum alloys [25-27].

The Al-Ca diagram is an eutectic type one [4,28-30]. However, unlike silicon, calcium does not form phases with magnesium (in the aluminum-rich region) [31]. The $\mathrm{Al}_{4} \mathrm{Ca}$ compound is in equilibrium with Al. However, in the Al-Ca-Si ternary system, there is the compound $\mathrm{Al}_{2} \mathrm{CaSi}_{2}[4,32,33]$, which does not allow the distribution of calcium and silicon between three possible phases $\left(\mathrm{Al}_{4} \mathrm{Ca}\right.$, $\mathrm{Mg}_{2} \mathrm{Si}$ and $\mathrm{Al}_{2} \mathrm{CaSi}_{2}$ ) in the quaternary Al-Ca-Mg-Si system. Thus, to assess the appropriateness of joint calcium and silicon alloying of the aluminum-magnesium alloys, analysis of the quaternary Al-Ca-Mg-Si system is required. In this system, calcium is the main eutectic-forming element, and it largely determines the castability of the alloys [30,34]. In addition, calcium can has a positive effect on corrosion resistance. Magnesium has a high solubility in aluminum, and enables considerable hardening at concentrations above 5\% [2-4,35]. Silicon can enter into the composition of complex multicomponent eutectics with a fine structure, which can be favorable for mechanical properties. We expect that the new alloys will be useful for the production of shaped castings with low density and high corrosion resistance. The use of these composite alloys for the production of metallic glass is hardly possible due to the low glass-forming ability [36-38] determined by their chemical composition (in particular, a high content of magnesium and the absence of refractory transition metals).

As this quaternary system has not yet been studied in detail, the main aims of this study are as follows:

- To study the phase diagram of the Al-Ca-Mg-Si system using thermodynamic calculations and experimental methods. It should be noted that the analysis of phase equilibria will be conducted with respect to conventional branded aluminum alloys technology of a liquid solidification, with a cooling rate range of $1-10 \mathrm{~K} / \mathrm{s}$.

- To experimentally investigate the combined effect of $\mathrm{Ca}$ and $\mathrm{Si}$ additions on the structure, phase composition, and specific properties of Al-Mg alloys.

- To identify and justify promising compositions for the development of new corrosion-resistant alloys with reduced density.

\section{Materials and Methods}

The objects of the experimental study were the Al4Ca12Mg, Al6Ca2.5Mg, Al10Ca10Mg2Si, Al4Ca10Mg2Si, Al3Ca10Mg1Si and Al10Mg alloys, the calculated phase compositions of which are considered below (Table 1).

Table 1. Calculated phase fractions for selected alloys of the Al-Ca-Mg-Si system.

\begin{tabular}{|c|c|c|c|c|c|c|c|c|c|}
\hline \multirow{3}{*}{ Alloy } & \multirow{3}{*}{$\mathrm{t} T\left({ }^{\circ} \mathrm{C}\right)$} & \multicolumn{8}{|c|}{ Phases } \\
\hline & & \multicolumn{2}{|c|}{ (Al) } & \multicolumn{2}{|c|}{$\mathrm{Al}_{4} \mathrm{Ca}$} & \multicolumn{2}{|c|}{$\mathrm{Mg}_{2} \mathrm{Si}$} & \multicolumn{2}{|c|}{$\mathrm{Al}_{3} \mathrm{Mg}_{2}$} \\
\hline & & $Q_{M}{ }^{1}$ & $Q_{\mathrm{V}}{ }^{2}$ & $Q_{M}{ }^{1}$ & $Q_{V^{2}}$ & $Q_{M}{ }^{1}$ & $Q_{V^{2}}$ & $Q_{M}{ }^{1}$ & $Q_{\mathrm{V}}{ }^{2}$ \\
\hline \multirow{2}{*}{ Al10Mg10Ca2Si } & 200 & 43.46 & 39.20 & 36.93 & 38.27 & 5.46 & 7.07 & 14.15 & 15.45 \\
\hline & 440 & 57.71 & 53.50 & 36.83 & 39.23 & 5.46 & 7.27 & 0 & 0 \\
\hline \multirow{2}{*}{$\mathrm{Al} 10 \mathrm{Mg} 4 \mathrm{Ca} 2 \mathrm{Si}$} & 200 & 67.95 & 63.36 & 14.77 & 15.85 & 5.46 & 7.32 & 11.92 & 13.48 \\
\hline & 440 & 79.96 & 76.48 & 14.58 & 16.02 & 5.46 & 7.50 & 0 & 0 \\
\hline \multirow{2}{*}{ Al10Mg3Ca1Si } & 200 & 69.64 & 65.48 & 11.08 & 11.97 & 2.73 & 3.69 & 16.56 & 18.86 \\
\hline & 440 & 86.37 & 84.01 & 10.90 & 12.18 & 2.73 & 3.81 & 0 & 0 \\
\hline
\end{tabular}

${ }^{1} Q_{\mathrm{M}}$-weight fraction, $\% .{ }^{2} Q_{\mathrm{V}}$-volume fraction, $\%$. 
The smelting was conducted in an electric resistance furnace (OOO LAC, Rajhrad, Czech Republic) in clay-graphite crucibles. All alloys were prepared using high purity $\mathrm{Al}(99.99 \%)$ with additions of pure alloying components of $\mathrm{Ca} 99.9 \%, \mathrm{Mg} 99.9 \%$ and $\mathrm{Si} 99.9 \%$. The melt was poured into a graphite mold at $730{ }^{\circ} \mathrm{C}-740{ }^{\circ} \mathrm{C}$ to produce flat castings with a size of $15 \mathrm{~mm} \times 30 \mathrm{~mm} \times 180 \mathrm{~mm}$ (the cooling rate during solidification was about $10 \mathrm{~K} / \mathrm{s}$ ). The chemical composition was controlled with an ARL 4460 optical emission spark spectrometer (Thermo Fisher Scientific, Waltham, MA, USA). The actual concentrations of $\mathrm{Si}, \mathrm{Cu}$, and $\mathrm{Sn}$ were very close to the nominal values.

The heat treatment of the castings was carried out in a SNOL muffle electric furnace (AB "UMEGA", Utena, Lithuania) at $440{ }^{\circ} \mathrm{C}$ for $3 \mathrm{~h}$ followed by quenching in water (T4 temper). To evaluate the effect of the alloys composition on the distribution of $\mathrm{Al}_{3} \mathrm{Mg}_{2}$ precipitates, artificial aging at $200{ }^{\circ} \mathrm{C}$ was carried out for $3 \mathrm{~h}$ after quenching.

The structures of the as-cast and heat-treated samples were examined by means of optical (OM, Axiovert 200 MMAT, Carl Zeiss, Oberkochen, Germany) and scanning electron (SEM, TESCAN, VEGA 3, Tescan Orsay Holding, Brno, Czech Republic) microscopes, and by electron microprobe analysis (EMPA, OXFORD Aztec, Oxford Instruments, Oxfordshire, UK). The samples were cut from the castings, ground, and polished using conventional procedures. Mechanical polishing (Struers Labopol-5, Struers, Copenhagen, Denmark) was applied. The study of the fine structure, particularly for determining the precipitates of $\mathrm{Al}_{3} \mathrm{Mg}_{2}$ phase, was conducted under a transmission electron microscope JEM2100 (TEM, JEOL Ltd, Tokyo, Japan) at an accelerating voltage of $200 \mathrm{kV}$. The sample foil plates were cut from the ingots. The foil disks were thinned in a Struers device (Struers, Copenhagen, Denmark) for electrolytic preparation of specimens at a voltage of $15 \mathrm{~V}$ and a temperature of $-40{ }^{\circ} \mathrm{C}$ in a chlorine-alcohol electrolyte solution $\left(\mathrm{C}_{2} \mathrm{H}_{5} \mathrm{OH}\right.$ with $\left.10 \% \mathrm{HClO}_{4}\right)$.

X-ray analysis was carried out on a Bede D1 System (Bruker, Karlsruhe, Germany) with $\mathrm{Cu}$ $\mathrm{K} \alpha$ radiation $(\lambda=0.15406 \mathrm{~nm})$. The objects of the X-ray diffraction (XRD) study were fine powder specimens (up to $50 \mu \mathrm{m}$ in diameter) cut from part of the ingots.

The Brinell hardness was determined in a INNOVATEST (series NEMESIS 9000, INNOVATEST, Maastricht, The Netherlands) hardness testing machine with a $2.5 \mathrm{~mm}$ diameter ball and a $612.9 \mathrm{~N}$ load for a $30 \mathrm{~s}$ dwell time.

The density was determined using the Archimedes method. The test sample was weighed on a HR-202i laboratory electronic scale in air $\left(m_{1}\right)$ and in water $\left(m_{2}\right)$. Then, the density was defined as:

$$
\rho=\frac{m_{1} \cdot\left(\rho_{\omega}-\rho_{\mathrm{a}}\right)}{m_{1}-m_{2}}+\rho_{\mathrm{a}}
$$

where $\rho_{\omega}$ is the density of water, $\mathrm{kg} / \mathrm{m}^{3} ; \rho_{\mathrm{a}}$ is the density of air, $\mathrm{kg} / \mathrm{m}^{3}$.

Tests for intergranular corrosion were carried out in a $3 \%$ solution of $\mathrm{NaCl}+1 \% \mathrm{HCl}$ solution at a temperature of $20^{\circ} \mathrm{C}$ for $24 \mathrm{~h}$.

Differential Scanning Calorimetry (DSC) with a heating and cooling rate of $10 \mathrm{~K} / \mathrm{min}$ was performed using a high-temperature DSC Setaram Setsys Evolution (SETARAM Instrumentation, Caluire, France) on specimens with a mass of $\sim 80 \mathrm{mg}$. The experiment was carried out in a dynamic Ar atmosphere with a flow rate of $50 \mathrm{~mL} / \mathrm{min}$. A temperature accuracy of $\pm 0.5{ }^{\circ} \mathrm{C}$ was obtained.

We used the Thermo-Calc software (TTAL5 database [39]) to calculate the phase composition.

\section{Results and Discussion}

\subsection{Analysis of Al-Ca-Mg-Si Phase Diagram}

The TTAL5 database is designed to calculate the phase composition of multicomponent aluminum-based alloys, and contains the thermodynamic values of all the chemical elements of a given quaternary system and the expected phases: $\mathrm{Al}_{3} \mathrm{Mg}_{2}, \mathrm{Al}_{4} \mathrm{Ca}, \mathrm{Mg}_{2} \mathrm{Si}, \mathrm{Al}_{2} \mathrm{CaSi}_{2}$, (Si) [33,34]. The characteristics of these phases are given in Table 2. 
Table 2. Characteristics of phases in the Al-rich alloys of Al-Ca-Mg-Si system [2,4,32,35].

\begin{tabular}{|c|c|c|c|c|c|}
\hline \multirow{2}{*}{ Formula } & \multicolumn{2}{|c|}{ Composition } & \multirow{2}{*}{ Crystal Lattice } & \multirow{2}{*}{$\begin{array}{l}\text { Density, } \\
\mathrm{g} / \mathrm{cm}^{3}\end{array}$} & \multirow{2}{*}{$\begin{array}{l}\text { Hardness, } \\
\text { HV }\end{array}$} \\
\hline & wt $\%$ & at $\%$ & & & \\
\hline $\mathrm{Al}_{4} \mathrm{Ca}$ & $27 \mathrm{Ca}$ & $20 \mathrm{Ca}$ & $\begin{array}{c}\text { Tetr. I4/mmm, } 10 \text { atoms } / \text { cell, } \\
\mathrm{a}=4.36 ; \AA \mathrm{c}=11.09 \AA\end{array}$ & 2.35 & $200-260$ \\
\hline $\mathrm{Mg}_{2} \mathrm{Si}$ & $\begin{array}{l}63.2 \mathrm{Mg} \\
36.8 \mathrm{Si}\end{array}$ & $\begin{array}{c}66.7 \mathrm{Mg} \\
33.3 \mathrm{Si}\end{array}$ & $\begin{array}{l}\text { Cub. Fm3m, } 12 \text { atoms / cell } \\
a=6.35-6.40 \AA\end{array}$ & 1.88 & 450 \\
\hline $\mathrm{Al}_{3} \mathrm{Mg}_{2}$ & $37.3 \mathrm{Mg}$ & $40 \mathrm{Mg}$ & Hex. Pm3m, 108 atoms/cell & 2.23 & $200-340$ \\
\hline $\mathrm{Al}_{2} \mathrm{CaSi}_{2}$ & $\begin{array}{l}26.7 \mathrm{Ca} \\
37.3 \mathrm{Si}\end{array}$ & $\begin{array}{l}20 \mathrm{Ca} \\
40 \mathrm{Si}\end{array}$ & $\begin{array}{c}\text { Hex. P3m1, } 5 \text { atoms } / \text { cell } \\
\mathrm{A}=4.13 ; \AA \mathrm{C}=7.15 \AA\end{array}$ & $2.36^{3}$ & $?$ \\
\hline$(\mathrm{Si})$ & $100 \mathrm{Si}$ & $100 \mathrm{Si}$ & Cub. $\mathrm{Fd} 3 \mathrm{~m}$ a $=5.43 \AA$ & 2.6 & 870 \\
\hline
\end{tabular}

Initially, on the basis of the calculation of phase equilibria, the general structure of this quaternary system in the Al-corner was proposed in the form of a polythermal diagram (projection of the solidification surfaces) $[4,35]$. According to Figure 1, three quaternary phase fields can be in the solid state: $(\mathrm{Al})+\mathrm{Al}_{3} \mathrm{Mg}_{2}+\mathrm{Al}_{4} \mathrm{Ca}+\mathrm{Mg}_{2} \mathrm{Si}$, (Al) $+\mathrm{Al}_{4} \mathrm{Ca}+\mathrm{Mg}_{2} \mathrm{Si}+\mathrm{Al}_{2} \mathrm{CaSi}_{2}$, and (Al) $+\mathrm{Mg}_{2} \mathrm{Si}$ $+\mathrm{Al}_{2} \mathrm{CaSi}_{2}+(\mathrm{Si})$. Thus, the ternary compound cannot be in equilibrium with $\mathrm{Al}_{3} \mathrm{Mg}_{2}$. The fields correspond to the binary eutectic reactions $(\mathrm{L} \rightarrow(\mathrm{Al})+\beta$, where $\beta$ is the second phase), the lines correspond to the ternary eutectics $\left(\mathrm{L} \rightarrow(\mathrm{Al})+\beta_{1}+\beta_{2}\right)$, and the points correspond to the invariant reactions. The temperatures of these invariant reactions, as well as the compositions of the liquid phase and $(\mathrm{Al})$, are given in Table 3. In alloys with high magnesium content, there is a eutectic reaction $\mathrm{L} \rightarrow$ $(\mathrm{Al})+\mathrm{Al}_{4} \mathrm{Ca}+\mathrm{Mg}_{2} \mathrm{Si}+\mathrm{Al}_{3} \mathrm{Mg}_{2}$, and another eutectic reaction is $\mathrm{L} \rightarrow(\mathrm{Al})+\mathrm{Al}_{4} \mathrm{Ca}+\mathrm{Mg}_{2} \mathrm{Si}+(\mathrm{Si})$ in the alloys with high silicon content (points $\mathrm{E}_{1}$ and $\mathrm{E}_{2}$ in Figure 1, respectively).

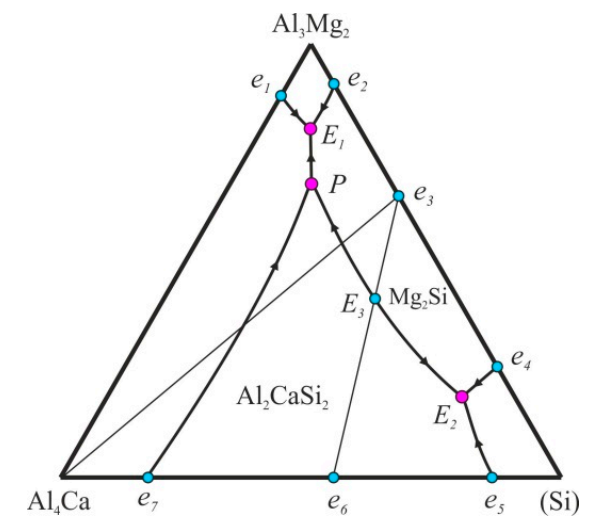

Figure 1. Polythermal projection of the Al-Ca-Mg-Si system in the aluminum corner.

In terms of temperature and phase composition, these five-phase reactions are close to the corresponding four-phase reactions in the Al-Mg-Si system (points $\mathrm{e}_{2}$ and $\mathrm{e}_{4}$ in Figure 1). The point $\mathrm{P}$ corresponds to the peritectic reaction $\mathrm{L}+\mathrm{Al}_{2} \mathrm{CaSi}_{2} \rightarrow(\mathrm{Al})+\mathrm{Al}_{4} \mathrm{Ca}+\mathrm{Mg}_{2} \mathrm{Si}$. If we assume the existence of the quasi-ternary cross-section $\mathrm{Al}_{-}-\mathrm{Al}_{2} \mathrm{CaSi}_{2}-\mathrm{Mg}_{2} \mathrm{Si}$, then one more invariant reaction $\mathrm{L} \rightarrow(\mathrm{Al})+$ $\mathrm{Al}_{4} \mathrm{Ca}+\mathrm{Mg}_{2} \mathrm{Si}$ is possible in the quaternary system (point E3). Such situations are typical of some other quaternary systems, such as Al-Cu-Mg-Si and Al-Fe-Mg-Si [4,34].

Then, a qualitative analysis of phase transformations was performed using the calculated liquidus projections and vertical cross-sections. Finally, to obtain quantitative estimates, calculations of phase fractions and chemical compositions were performed at the temperatures of the phase transformations. 
Table 3. Calculated parameters of invariant reactions in the Al-Ca-Mg-Si system.

\begin{tabular}{|c|c|c|c|c|c|c|c|}
\hline \multirow{2}{*}{ Reaction } & \multirow{2}{*}{$\begin{array}{l}\text { Point in } \\
\text { Figure } 1\end{array}$} & \multirow{2}{*}{$T,{ }^{\circ} \mathrm{C}$} & \multicolumn{5}{|c|}{ Concentration, wt \% } \\
\hline & & & Phase & Al & $\mathrm{Ca}$ & Mg & Si \\
\hline \multirow{2}{*}{$\mathrm{L} \rightarrow(\mathrm{Al})+\mathrm{Al}_{4} \mathrm{Ca}+\mathrm{Mg}_{2} \mathrm{Si}+\mathrm{Al}_{3} \mathrm{Mg}_{2}$} & \multirow{2}{*}{$\mathrm{E}_{1}$} & \multirow{2}{*}{448} & $\mathrm{~L}$ & 65.86 & 0.67 & 33.38 & 0.08 \\
\hline & & & $(\mathrm{Al})$ & 84.09 & 0.04 & 15.87 & $<0.01$ \\
\hline \multirow{2}{*}{$\mathrm{L} \rightarrow(\mathrm{Al})+\mathrm{Al}_{2} \mathrm{CaSi}_{2}+\mathrm{Mg}_{2} \mathrm{Si}+(\mathrm{Si})$} & \multirow{2}{*}{$E_{2}$} & \multirow{2}{*}{558} & $\mathrm{~L}$ & 81.74 & $<0.01$ & 4.67 & 13.59 \\
\hline & & & $(\mathrm{Al})$ & 98.00 & $<0.01$ & 0.64 & 1.35 \\
\hline \multirow{2}{*}{$\mathrm{L}+\mathrm{Al}_{2} \mathrm{CaSi}_{2} \rightarrow(\mathrm{Al})+\mathrm{Al}_{4} \mathrm{Ca}+\mathrm{Mg}_{2} \mathrm{Si}$} & \multirow{2}{*}{$\mathrm{P}$} & \multirow{2}{*}{563} & $\mathrm{~L}$ & 83.25 & 3.93 & 12.00 & 0.83 \\
\hline & & & $(\mathrm{Al})$ & 95.34 & 0.33 & 4.29 & 0.64 \\
\hline \multirow{2}{*}{$\mathrm{L} \rightarrow(\mathrm{Al})+\mathrm{Al}_{2} \mathrm{CaSi}_{2}+\mathrm{Mg}_{2} \mathrm{Si}^{4}$} & \multirow{2}{*}{$\mathrm{E}_{3}$} & \multirow{2}{*}{594} & $\mathrm{~L}$ & 86.11 & 0.26 & 8.92 & 4.71 \\
\hline & & & $(\mathrm{Al})$ & 97.55 & 0.02 & 2.11 & 0.32 \\
\hline
\end{tabular}

${ }^{4}$ In quasi-ternary section.

Since the primary crystals of the second phases are certainly undesirable, we calculated the liquidus surfaces. In the ternary $\mathrm{Al}-\mathrm{Ca}-\mathrm{Mg}$ system, with an increase in the magnesium content, the eutectic polytherm (corresponding to the reaction $\mathrm{L} \rightarrow(\mathrm{Al})+\mathrm{Al}_{4} \mathrm{Ca}$ ) shifts toward the lower calcium concentrations (Figure 2a). On the basis of this polytherm, two ternary alloys-Al- $4 \% \mathrm{Ca}-12 \%$ $\mathrm{Mg}$ and $\mathrm{Al}-6 \% \mathrm{Ca}-2.5 \% \mathrm{Mg}$, hereinafter Al12Mg4Ca and Al2.5Mg6Ca-were chosen for further consideration. According to their positions in the diagram (marked in Figure 2a), these alloys should have near-eutectic microstructures.

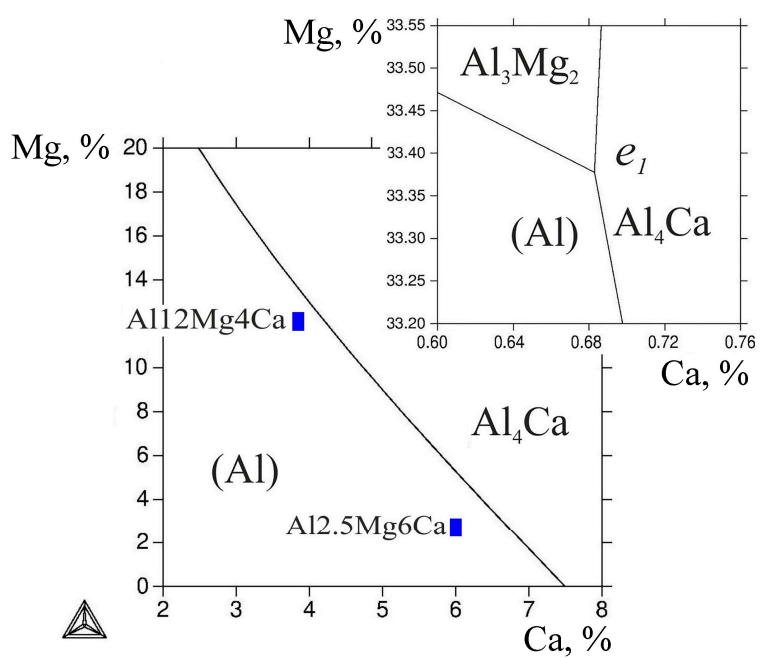

(a)

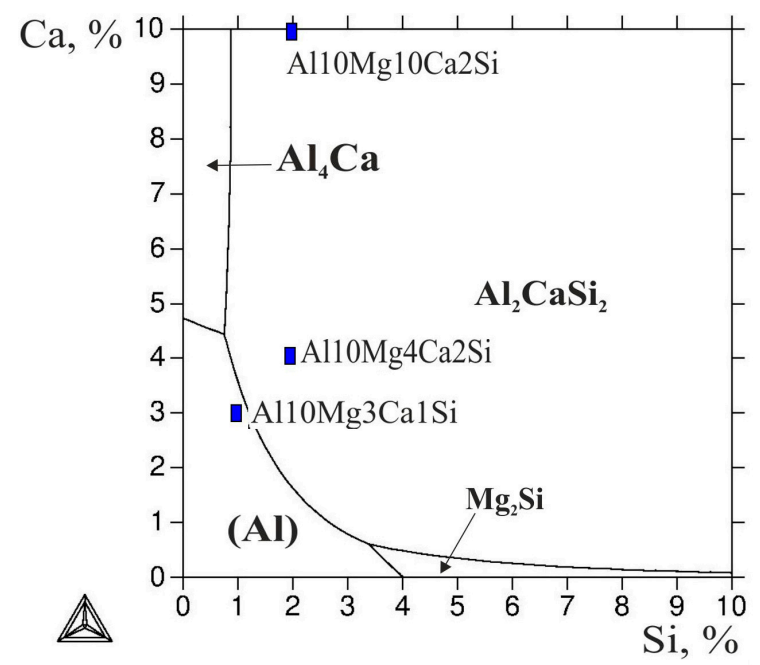

(b)

Figure 2. The calculated liquidus projection of systems $\mathrm{Al}-\mathrm{Ca}-\mathrm{Mg}$ (a) and $\mathrm{Al}-\mathrm{Ca}-\mathrm{Mg}-\mathrm{Si}(\mathbf{b})$ at $10 \mathrm{wt} \% \mathrm{Mg}$.

For the quaternary system, the liquidus projection was calculated at $10 \% \mathrm{Mg}$. It can be seen from Figure $2 \mathrm{~b}$ that the major part of the calculated concentration range is covered by the region of the primary crystallization of the $\mathrm{Al}_{2} \mathrm{CaSi}_{2}$ phase. Even at high calcium contents, $1 \% \mathrm{Si}$ is sufficient to make this ternary compound crystallize first (rather than $\mathrm{Al}_{4} \mathrm{Ca}$ ). The areas of the primary crystallization of the $\mathrm{Al}_{4} \mathrm{Ca}$ and $\mathrm{Mg}_{2} \mathrm{Si}$ binary compounds are very narrow, and are located near the sides corresponding to the respective ternary systems (Al-Ca-Mg and $\mathrm{Al}-\mathrm{Mg}-\mathrm{Si}$ ).

For the quantitative analysis of the phase composition, three quaternary alloys were chosen: $\mathrm{Al}-10 \% \mathrm{Ca}-10 \% \mathrm{Mg}-2 \% \mathrm{Si}, \mathrm{Al}-4 \% \mathrm{Ca}-10 \% \mathrm{Mg}-2 \% \mathrm{Si}$, and $\mathrm{Al}-3 \% \mathrm{Ca}-10 \% \mathrm{Mg}-1 \% \mathrm{Si}$ (hereinafter Al10Mg10Ca2Si, Al10Mg4Ca2Si, and Al10Mg3Ca1Si, respectively). The positions of these alloys are shown in Figure 2b, from which it can be seen that the first two alloys fall into the region of primary crystallization of the $\mathrm{Al}_{2} \mathrm{CaSi}_{2}$ compound. In the Al10Mg3Ca1Si alloy, the primary crystals 
of the Ca- and Si-containing phase should not be formed, and the alloy should have a near eutectic microstructure. A general concept of the solidification character of quaternary alloys can be obtained from vertical sections, one of which is shown in Figure 3. The section calculated at $20 \% \mathrm{Mg}$ and $1 \%$ $\mathrm{Ca}$ (Figure 3a) shows that the primary magnesium silicide crystals should form even at low silicon contents (less than 1\%). The solidification of the alloys in this section containing up to $\sim 3.5 \%$ Si should end with the invariant eutectic reaction $\mathrm{L} \rightarrow(\mathrm{Al})+\mathrm{Al}_{4} \mathrm{Ca}+\mathrm{Mg}_{2} \mathrm{Si}+\mathrm{Al}_{3} \mathrm{Mg}_{2}$, the parameters of which are presented in Table 3.

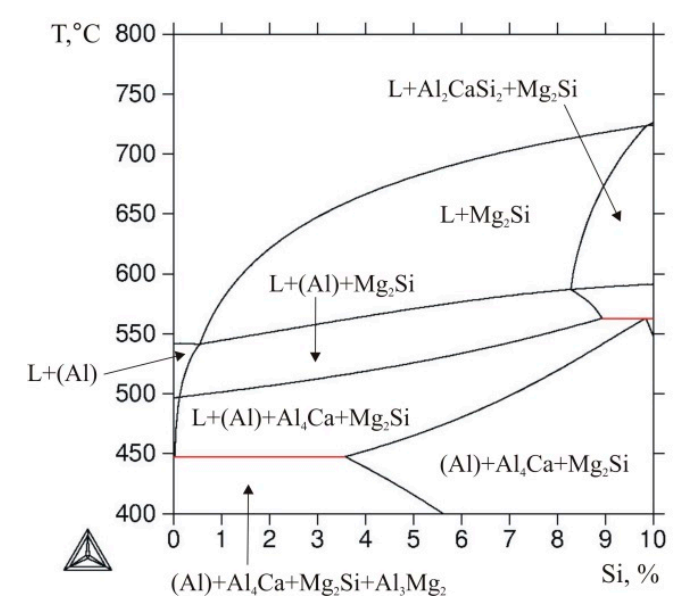

(a)

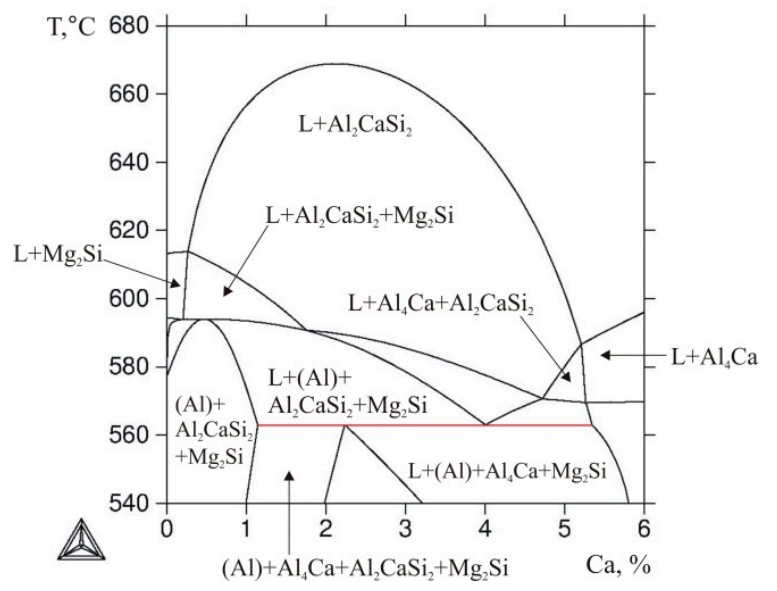

(b)

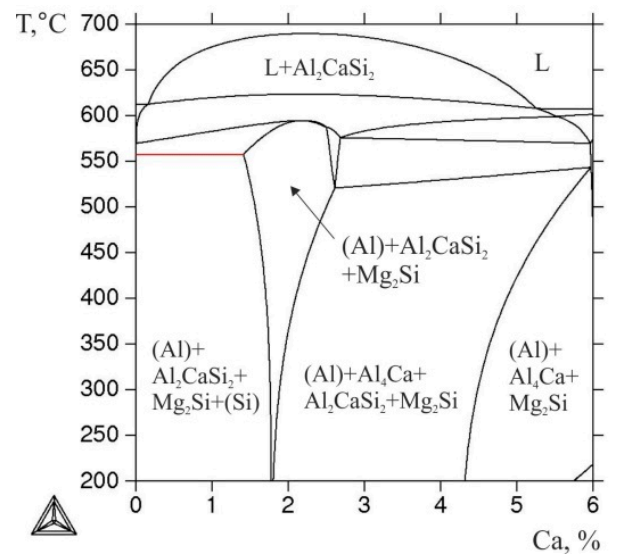

(c)

Figure 3. The calculated vertical cross sections of system Al-Ca-Mg-Si: (a) at 20\% $\mathrm{Mg}$ and $1 \% \mathrm{Ca}$; (b) at $10 \% \mathrm{Mg}$ and $84 \% \mathrm{Al}(\mathrm{Ca}+\mathrm{Si}=6 \%) ;($ c) at $3 \% \mathrm{Mg}$ and $91 \% \mathrm{Al}(\mathrm{Ca}+\mathrm{Si}=6 \%)$.

The most representative cross-section for the selected quaternary alloys is that for $10 \% \mathrm{Mg}$ and $84 \%$ Al. It can be seen from Figure $3 \mathrm{~b}$ that, in most alloys pertaining to this cross-section (where the total content of $\mathrm{Ca}$ and $\mathrm{Si}$ is constant and amounts to $6 \%$ ), the solidification starts with the formation of the $\mathrm{Al}_{2} \mathrm{CaSi}_{2}$ compound. At $3 \% \mathrm{Ca}$ and $3 \% \mathrm{Si}$, the liquidus temperature exceeds $650{ }^{\circ} \mathrm{C}$, which is significantly higher compared with the boundary ternary alloys (Al- $10 \% \mathrm{Mg}-6 \% \mathrm{Si}$ and $\mathrm{Al}-10 \% \mathrm{Mg}-6 \%$ $\mathrm{Ca}$ ). In the central region of the cross section, there is a horizontal line that corresponds to the invariant peritectic reaction $\mathrm{L}+\mathrm{Al}_{2} \mathrm{CaSi}_{2} \rightarrow(\mathrm{Al})+\mathrm{Al}_{4} \mathrm{Ca}+\mathrm{Mg}_{2} \mathrm{Si}$ (see Table 3 ). In alloys with an excess of silicon, this reaction ends with the disappearance of the liquid phase, i.e., such alloys complete the solidification in the four-phase region $(\mathrm{Al})+\mathrm{Al}_{4} \mathrm{Ca}+\mathrm{Mg}_{2} \mathrm{Si}+\mathrm{Al}_{2} \mathrm{CaSi}_{2}$. In alloys with a small amount of calcium, solidification ends with the monovariant eutectic reaction $\mathrm{L} \rightarrow(\mathrm{Al})+\mathrm{Al}_{2} \mathrm{CaSi}_{2}+\mathrm{Mg}_{2} \mathrm{Si}$. In this case, the solidus in this part of the polythermal section has a maximum (Figure $3 \mathrm{~b}$ ), which indicates an invariant 
nature of this eutectic reaction (for the alloy corresponding to the maximum point). This could confirm the assumption of the presence of a quasi-ternary $\mathrm{Al}-\mathrm{Al}_{2} \mathrm{CaSi}_{2}-\mathrm{Mg}_{2} \mathrm{Si}$ cross-section in the $\mathrm{Al}-\mathrm{Ca}-\mathrm{Mg}-\mathrm{Si}$ system (Figure 1).

In alloys with an excess of calcium, the ternary compound disappears as a result of an invariant peritectic reaction, and the solidification proceeds in accordance with the monovariant eutectic reaction $\mathrm{L} \rightarrow(\mathrm{Al})+\mathrm{Al}_{4} \mathrm{Ca}+\mathrm{Mg}_{2} \mathrm{Si}$, following which the alloy becomes three-phase. When the temperature is decreased, the $\mathrm{Al}_{3} \mathrm{Mg}_{2}$ compound is added to these phases as a result of the precipitation from (Al). It should also be noted that, even with the addition of negligible amounts of silicon to the Al- $10 \% \mathrm{Mg}-6 \%$ Ca boundary ternary alloy, magnesium silicide forms (Figure 3b) due to the very low solubility of Si in (Al). The vertical cross-section calculated at 3\% $\mathrm{Mg}$ and $91 \% \mathrm{Al}(\mathrm{Ca}+\mathrm{Si}=6 \%)$ reveals a horizontal line (Figure $3 \mathrm{c}$ ) corresponding to the invariant eutectic reaction $\mathrm{L} \rightarrow(\mathrm{Al})+\mathrm{Al}_{4} \mathrm{Ca}+\mathrm{Mg}_{2} \mathrm{Si}+(\mathrm{Si})$ (see Table 3), which determines the end of solidification in low calcium alloys.

Calculation of the critical temperature of the selected alloys shows that they are very different from each other (Table 4). In particular, the liquidus temperatures differ by almost $150{ }^{\circ} \mathrm{C}$, the Al10Mg10Ca2Si alloy has the highest value $\left(729^{\circ} \mathrm{C}\right)$, and the Al10Mg3Ca1Si alloy has the least $\left(583^{\circ} \mathrm{C}\right)$. According to the calculation, the quaternary alloys have the same phase composition in the solid state. In particular, as can be seen from Table 1 , at $200{ }^{\circ} \mathrm{C}$ they contain four phases: $(\mathrm{Al}), \mathrm{Al}_{4} \mathrm{Ca}$, $\mathrm{Mg}_{2} \mathrm{Si}$, and $\mathrm{Al}_{3} \mathrm{Mg}_{2}$. It should be noted that, even in the least alloyed Al10Mg3Ca1Si alloy, the total fraction of the second phases is $\sim 35 \mathrm{vol} \%$, which is typical for composites [40-42]. In the most alloyed Al10Mg10Ca2Si alloy, this fraction is more than half. At $440{ }^{\circ} \mathrm{C}$ (this value, as a rule, corresponds to the temperature of homogenization of $\mathrm{Al}-\mathrm{Mg}$ alloys), the $\mathrm{Al}_{3} \mathrm{Mg}_{2}$ phase is absent, and the content of the $\mathrm{Al}_{4} \mathrm{Ca}$ and $\mathrm{Mg}_{2} \mathrm{Si}$ phases remains almost unchanged (as compared with $200{ }^{\circ} \mathrm{C}$ ).

Table 4. Calculated critical temperatures of selected alloys of the Al-Ca-Mg-Si system.

\begin{tabular}{cccccc}
\hline Alloy & $\boldsymbol{T}_{\mathbf{L}}{ }^{\circ} \mathbf{C}$ & $\boldsymbol{T}_{\mathbf{S}},{ }^{\circ} \mathbf{C}$ & $\boldsymbol{\Delta} \boldsymbol{T},{ }^{\circ} \mathbf{C}$ & $\boldsymbol{T}_{\mathbf{N S}},{ }^{\circ} \mathbf{C}$ & $\boldsymbol{\Delta T}_{\mathbf{N S}},{ }^{\circ} \mathbf{C}$ \\
\hline Al12Mg4Ca & 566 & 463 & 103 & 448 & 118 \\
Al12.5Mg6Ca & 610 & 581 & 19 & 448 & 162 \\
Al10Mg10Ca2Si & 729 & 486 & 243 & 447 & 282 \\
Al10Mg4Ca2Si & 644 & 521 & 123 & 447 & 197 \\
Al10Mg3Ca1Si & 583 & 505 & 78 & 447 & 136 \\
Al10Mg & 609 & 513 & 96 & 450 & 159 \\
\hline
\end{tabular}

Since the actual solidification of most alloys is generally different from equilibrium, the evaluation of the phase composition of the casting or ingot in the as-cast state requires special techniques. One of the most commonly used techniques is the Scheil-Gulliver model, which is implemented in the Thermo-Calc program [33]. Figure 4 shows the nonequilibrium solidification curves (T-Q) calculated for the selected alloys using the given model. The Al-10\% $\mathrm{Mg}$ alloy was considered as the reference one, and its $T-Q$ curve is shown in Figure $4 \mathrm{a}$. In the Al12Mg4Ca and A12.5Mg6Ca ternary alloys, the eutectic reaction $\mathrm{L} \rightarrow(\mathrm{Al})+\mathrm{Al}_{4} \mathrm{Ca}$ starts almost immediately after the formation of the primary (Al) crystals (Figure $4 \mathrm{~b}, \mathrm{c}$ ). The solidification of these alloys ends with the invariant reaction $\mathrm{L} \rightarrow(\mathrm{Al})+$ $\mathrm{Al}_{4} \mathrm{Ca}+\mathrm{Al}_{3} \mathrm{Mg}_{2}$. The difference between these alloys is that in the former alloy, more than $20 \%$ of the liquid phase solidifies by this reaction, and in the latter one, about $2 \%$.

According to Figure 4d,e, in the Al10Mg10Ca2Si and Al10Mg4Ca2Si quaternary alloys, the first crystallizing compound was $\mathrm{Al}_{2} \mathrm{CaSi}_{2}$, which under equilibrium conditions should disappear as a result of the peritectic reaction. However, since the peritectic reactions, as a rule, do not complete during actual solidification of aluminum alloys [3], the presence of primary crystals of this ternary compound in the as-cast structure should be expected. It also follows from Figure $4 \mathrm{~d}-\mathrm{f}$ that the solidification of all alloys containing $\mathrm{Ca}$ and $\mathrm{Si}$ should be ended via the five-phase eutectic reaction, the parameters of which are given in Table 3. 


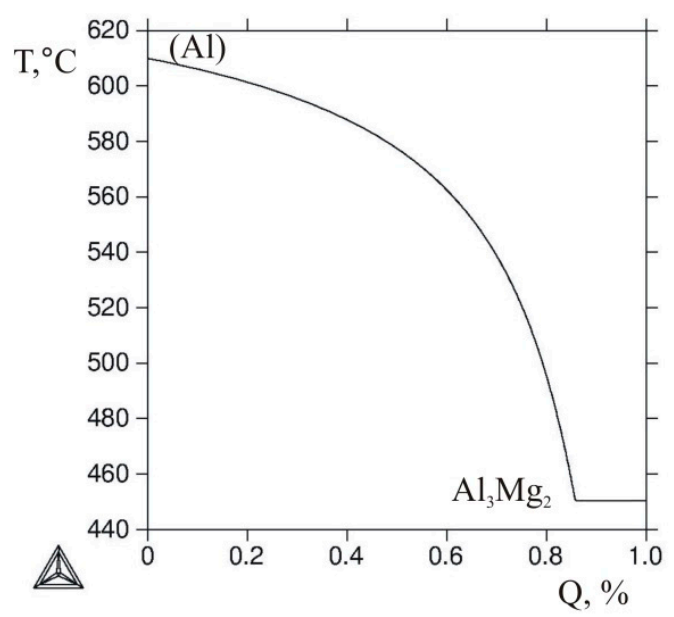

(a)

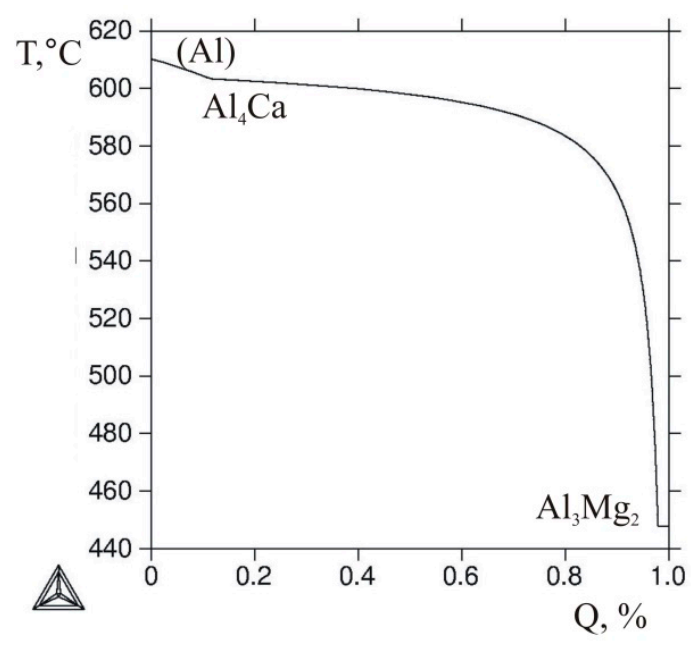

(c)

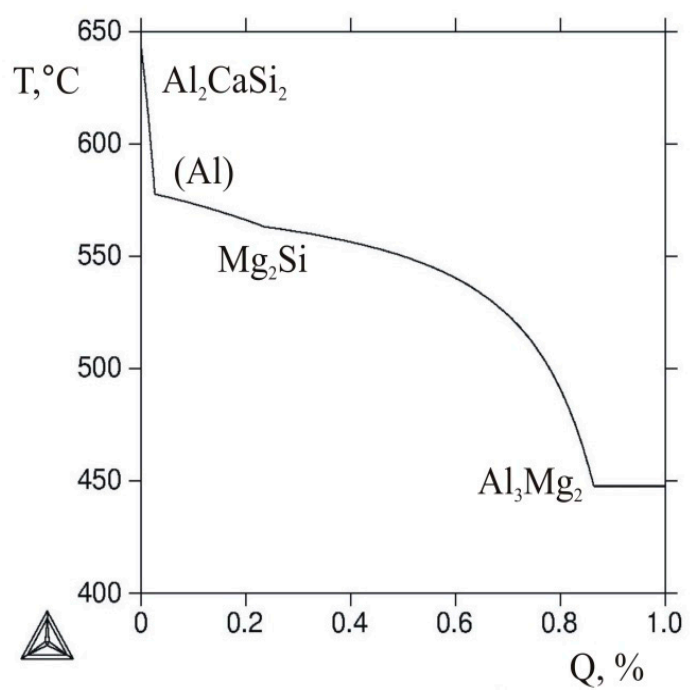

(e)

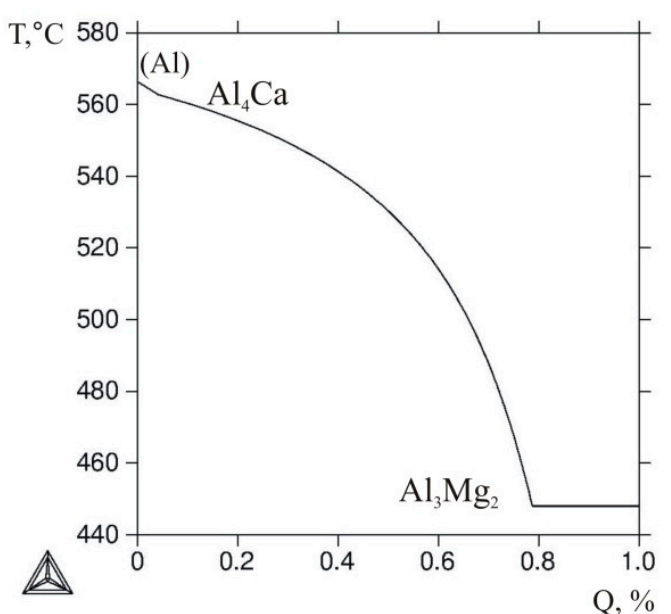

(b)

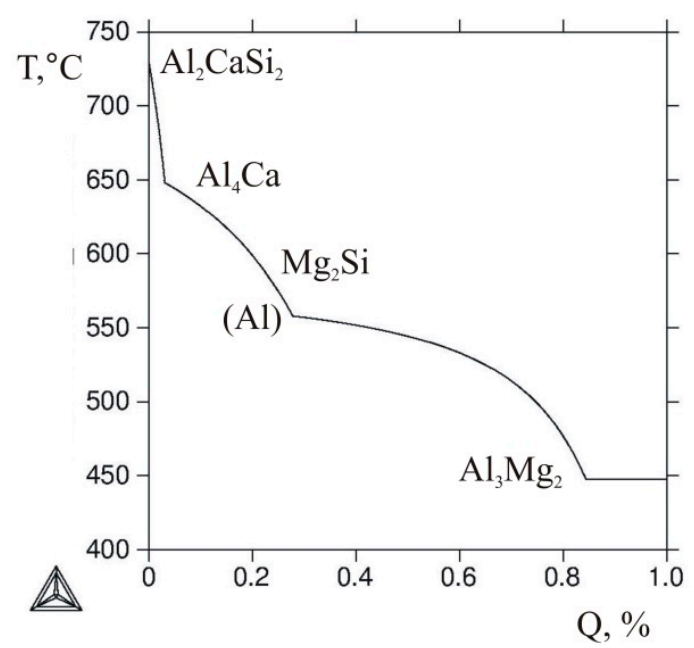

(d)

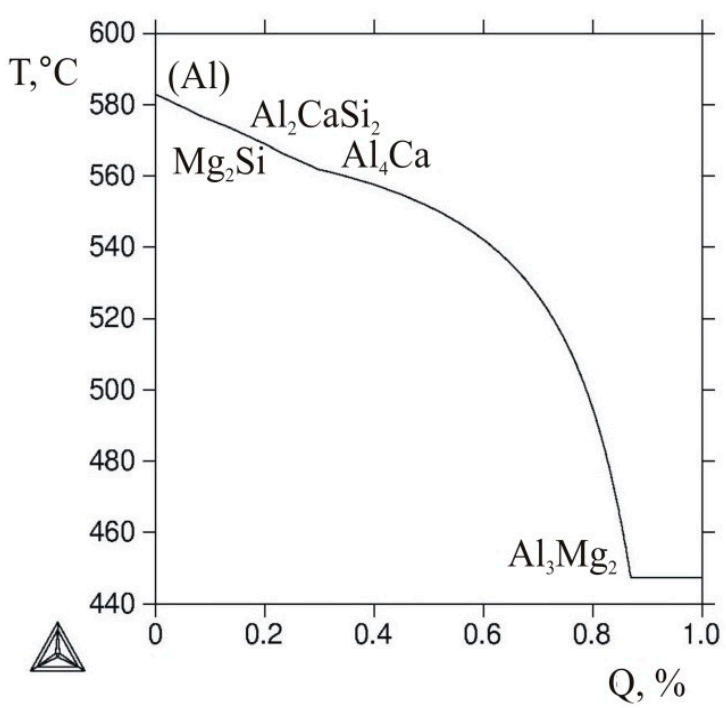

(f)

Figure 4. The calculated $Q-T$ curves (Sheil-Gulliver simulation) for the alloys: (a) Al10Mg; (b) Al12Mg4; (c) Al2.5Mg6Ca; (d) Al10Mg10Ca2Si; (e) Al10Mg4Ca2Si; (f) Al10Mg3Ca1Si. 


\subsection{Analysis of the Microstructure and Physical and Mechanical Properties}

The main structural component of the as-cast $\mathrm{A} 14 \mathrm{Ca} 12 \mathrm{Mg}$ and $\mathrm{Al} 6 \mathrm{Ca} 2.5 \mathrm{Mg}$ alloys is the $(\mathrm{Al})+$ $\mathrm{Al}_{4} \mathrm{Ca}$ eutectic (Figure 5a,b), which corresponds to the position of the alloys on the liquidus projection of the Al-Ca-Mg system (Figure 2a). In the Al6Ca2.5Mg alloy, the eutectic is coarser than in the Al4Ca12Mg alloy (Figure 5c,d). In the Al4Ca12Mg alloy, the veins of the $\mathrm{Al}_{3} \mathrm{Mg}_{2}$ phase are also distinguished, which is also characteristic of binary alloys (type 520). The leading phase in the formation of a Ca-containing eutectic with a relatively fine structure is the $\mathrm{Al}_{4} \mathrm{Ca}$ compound, as seen from Figure 5a.

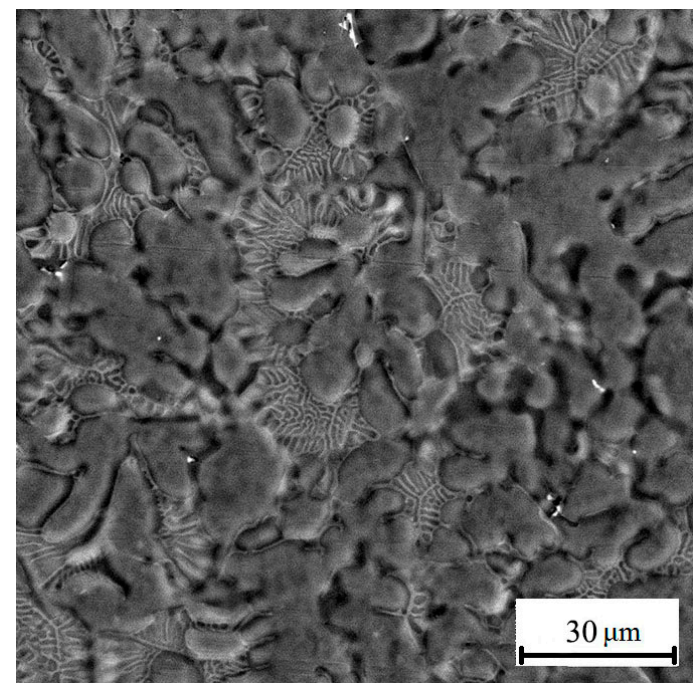

(a)

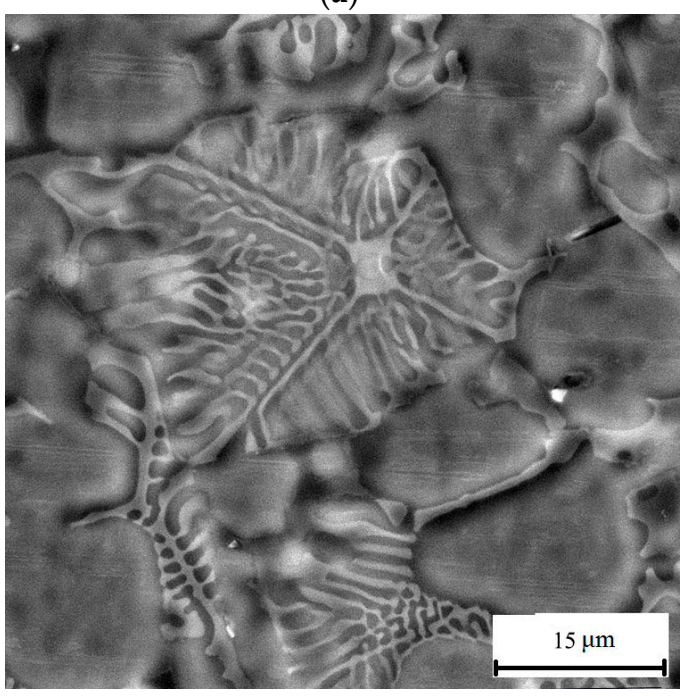

(c)

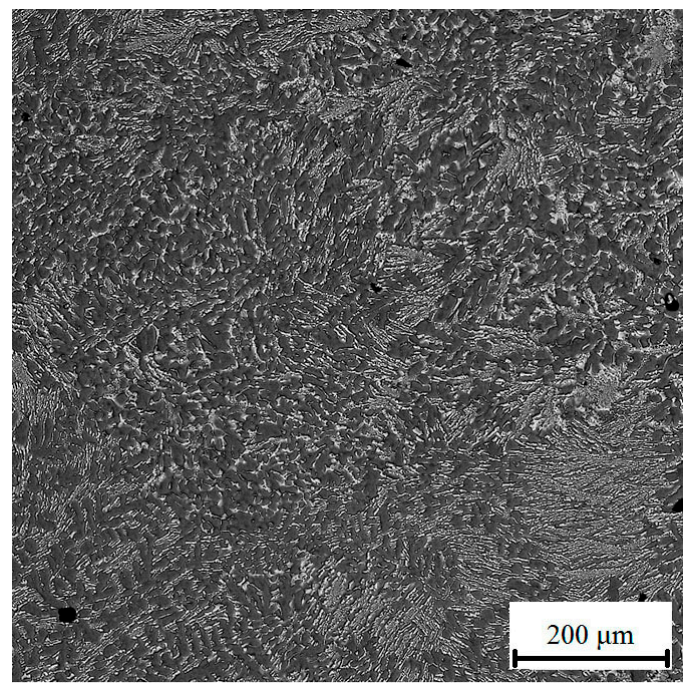

(b)

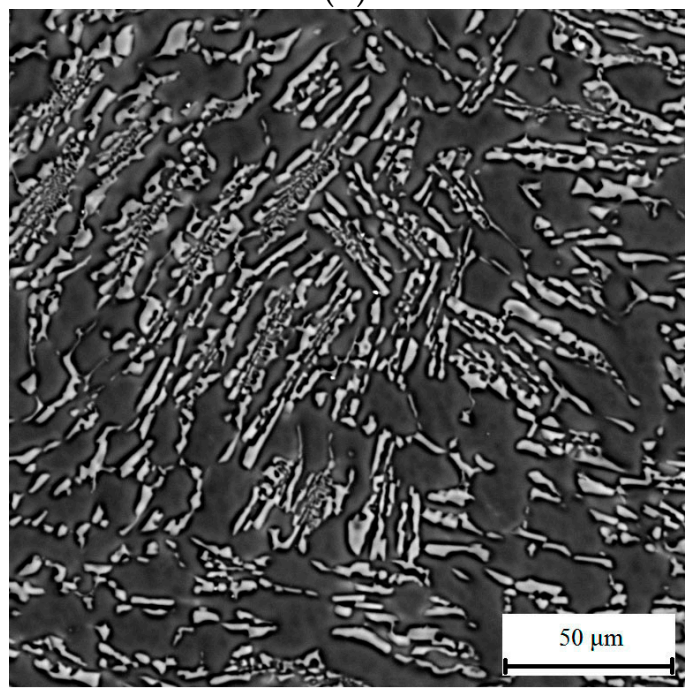

(d)

Figure 5. Microstructure of near-eutectic ternary alloys Al4Ca12Mg (a,c); and Al6Ca2.5Mg (b,d), scanning electron microscope (SEM) (Backscattered electrons (BSE)).

As we expected (see Figure 2b), the structure of the A110Mg10Ca2Si and Al10Mg4Ca2Si hypereutectic alloys is characterized by the presence of primary crystals of Ca-containing compounds, which are clearly revealed in the optical microscope (Figure 6). These crystals are enriched with calcium and silicon (Figure 7). The results of a quantitative analysis of the composition of these crystals, which was carried for the largest particles, show that in the A110Mg4Ca2Si alloy, they correspond sufficiently well to the compound $\mathrm{Al}_{2} \mathrm{CaSi}_{2}$ (Table 1). This experimental result agrees with the 
calculation according to which this particular ternary compound crystallizes first (Figure 4e). Some detectable amount of magnesium is probably associated with a high content of this element in the alloy and, as a consequence, with "backlighting".

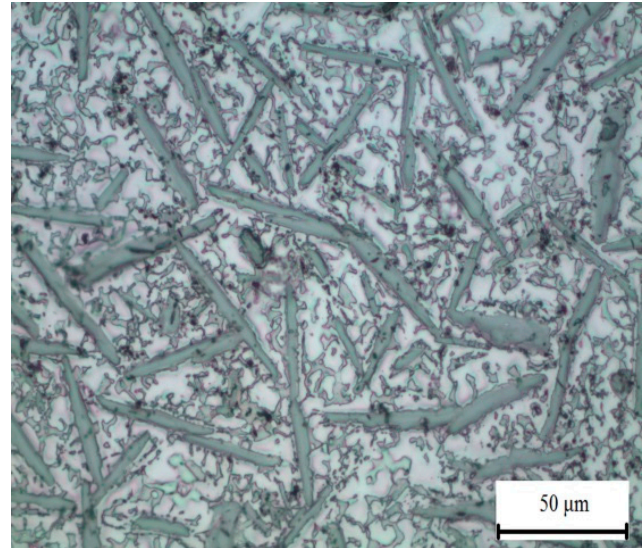

(a)

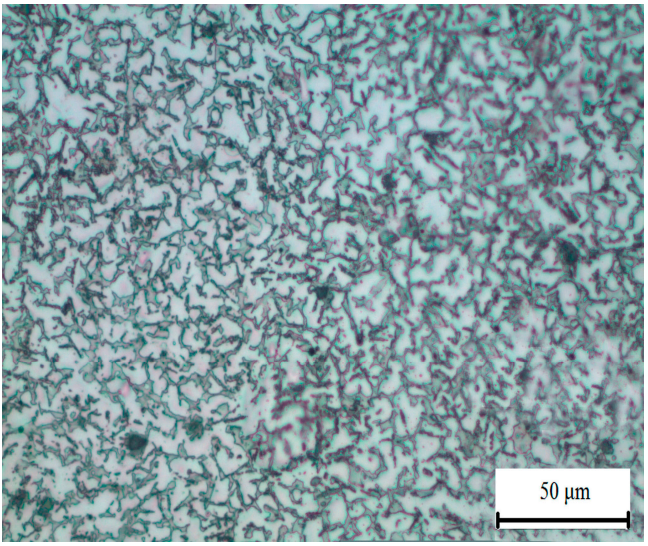

(b)

Figure 6. Primary crystals of Ca-containing phases in hyper-eutectic quaternary alloys Al10Mg10Ca2Si (a) and Al10Mg4Ca2Si (b), optical microscope (OM).

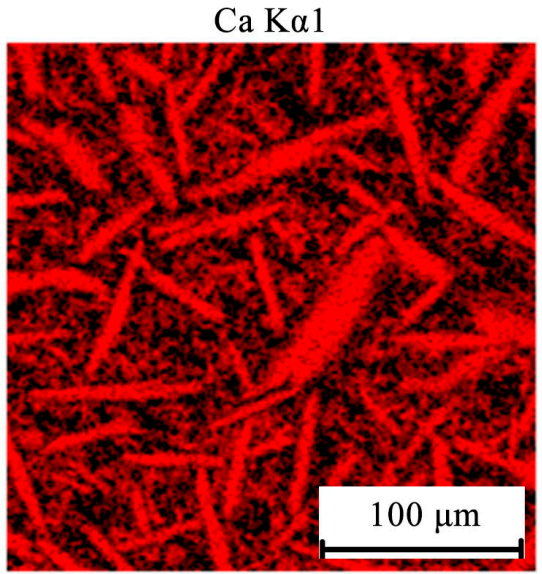

(a)

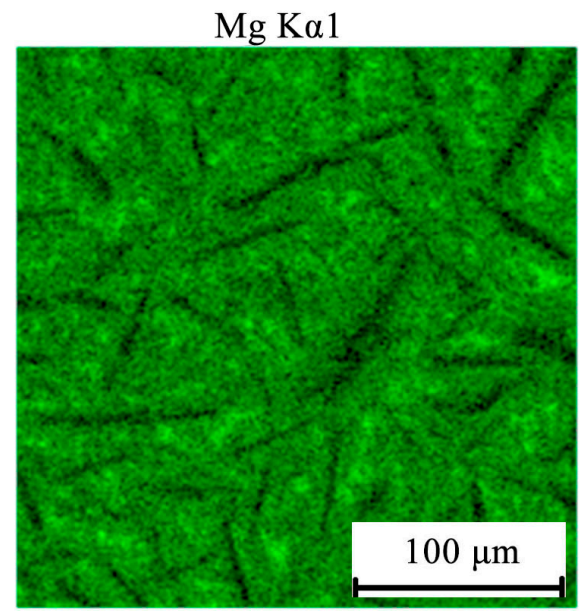

(c)

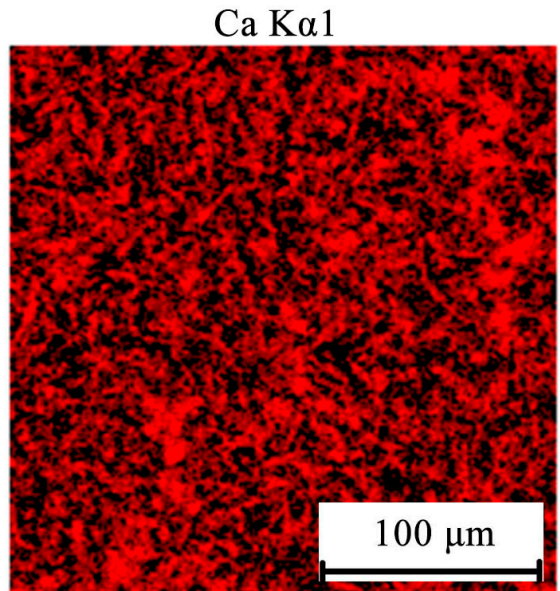

(b)

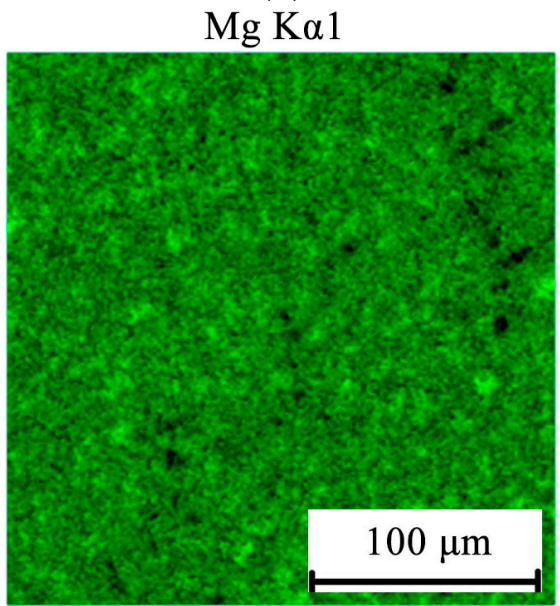

(d)

Figure 7. Cont. 


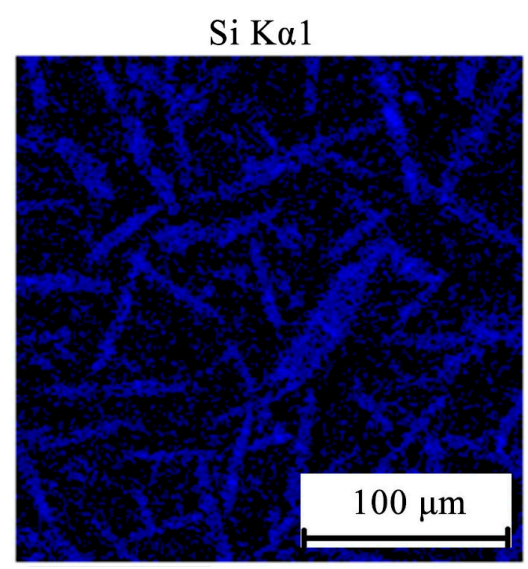

(e)

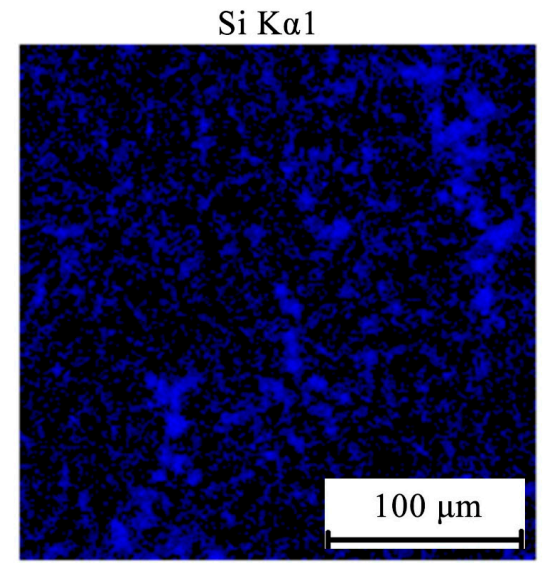

(f)

Figure 7. Electron microprobe analysis (EMPA) elemental mapping of $\mathrm{Ca}(\mathbf{a}, \mathbf{b}), \mathrm{Mg}(\mathbf{c}, \mathbf{d})$, and $\mathrm{Si}(\mathbf{e}, \mathbf{f})$ in hyper-eutectic alloys Al10Mg10Ca2Si (a,c,e) and Al10Mg4Ca2Si (b,d,f).

In the Al10Mg10Ca2Si alloy, the composition of the primary crystals (see Table 5) is close to the composition of $\mathrm{Al}_{4} \mathrm{Ca}$ aluminide (20 at \%). The presence of silicon in this alloy $(\sim 4 \%)$ can be attributed to the fact that the solidification of this alloy begins with the formation of a ternary compound (containing silicon), which follows from the calculation (Figure $4 \mathrm{~d}$ ). The maximum quantity of the $\mathrm{Al}_{2} \mathrm{CaSi}_{2}$ phase primary crystals according to the calculation is only $3 \mathrm{wt} \%$, which is several times smaller than the quantity of $\mathrm{Al}_{4} \mathrm{Ca}$ phase crystals that must form before the precipitation (Al). Presumably, the crystals of the ternary compound served as a substrate for the nucleation of binary aluminide crystals. Under equilibrium conditions, the ternary compound should disappear as a result of the peritectic reaction $\mathrm{L}+\mathrm{Al}_{2} \mathrm{CaSi}_{2} \rightarrow(\mathrm{Al})+\mathrm{Al}_{4} \mathrm{Ca}+\mathrm{Mg}_{2} \mathrm{Si}$. However, this reaction being incomplete under actual solidification conditions, the conglomerates of two phases formed, and the composition of these conglomerates is shown in Table 5.

Table 5. Chemical composition of primary crystals in alloys Al10Mg10Ca2Si and Al10Mg4Ca2Si.

\begin{tabular}{cccccc}
\hline \multirow{2}{*}{ Alloy } & \multicolumn{4}{c}{ Concentration, wt \% (at \%) } & \multirow{2}{*}{ Phase Identification } \\
\cline { 2 - 5 } & $\mathbf{M g}$ & $\mathbf{A l}$ & $\mathbf{S i}$ & $\mathbf{C a}$ & \\
\hline $10 \mathrm{Mg} 4 \mathrm{Ca} 2 \mathrm{Si}$ & $0.9(1.1)$ & $35.8(39.7)$ & $36.9(39.4)$ & $26.4(19.8)$ & $\mathrm{Al}_{2} \mathrm{CaSi}_{2}$ \\
$10 \mathrm{Mg} 10 \mathrm{Ca} 2 \mathrm{Si}$ & $2.9(3.5)$ & $64.5(71.0)$ & $4.1(4.3)$ & $28.6(21.2)$ & $\mathrm{Al}_{4} \mathrm{Ca}\left(+\mathrm{Al}_{2} \mathrm{CaSi}_{2}\right)$ \\
\hline
\end{tabular}

In the Al10Mg3Ca1Si alloy, whose structure is close to eutectic, no primary crystals of Caand Si-containing phases were detected (Figure 8a,b), which agrees with the results of the phase composition calculation (see Figures $2 \mathrm{~b}$ and $4 \mathrm{e}$ ). The $\mathrm{Al}_{3} \mathrm{Mg}_{2}$ phase inclusions that are typical of the as-cast structure of the Al10Mg reference alloy (Figure 9a) are difficult to detect against the background of the eutectic alloy with a rather fine structure. During the $440{ }^{\circ} \mathrm{C}$ anneal, these inclusions dissolve,

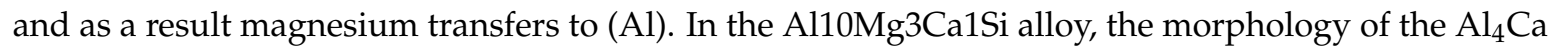
eutectic phase particles varies slightly compared with the as-cast state. No evidence of fragmentation was revealed by TEM (Figure 8c). During the $200{ }^{\circ} \mathrm{C}$ heating, $50 \mathrm{~nm}$ secondary $\mathrm{Al}_{3} \mathrm{Mg}_{2}$ precipitates form, and are distributed quite homogeneously (Figure $8 \mathrm{~d}$ ). In this alloy, there are no grain boundary chains of precipitates that are typical of the Al10Mg binary alloy after similar heat treatment (Figure 9b). 


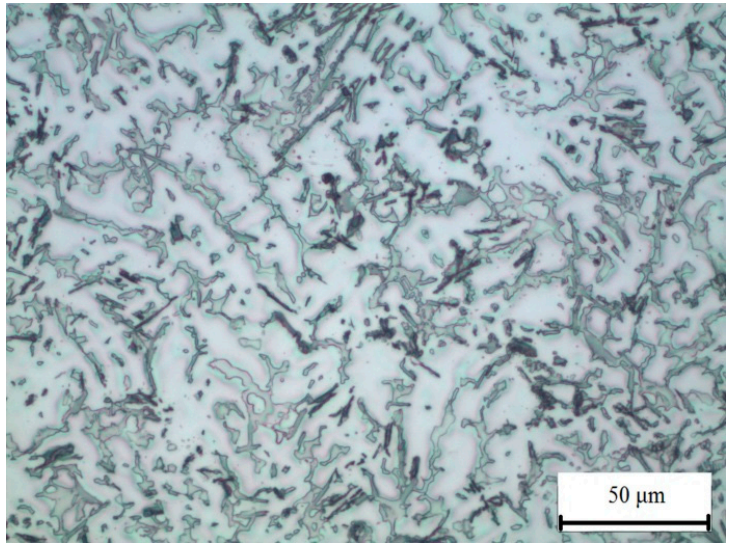

(a)

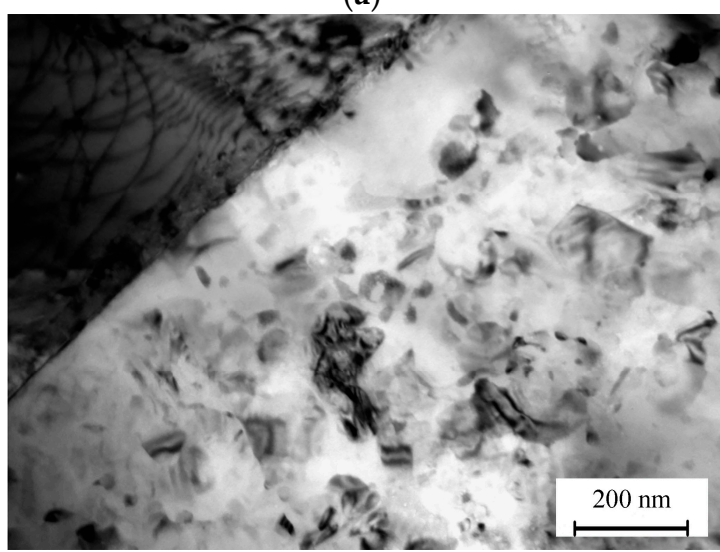

(c)

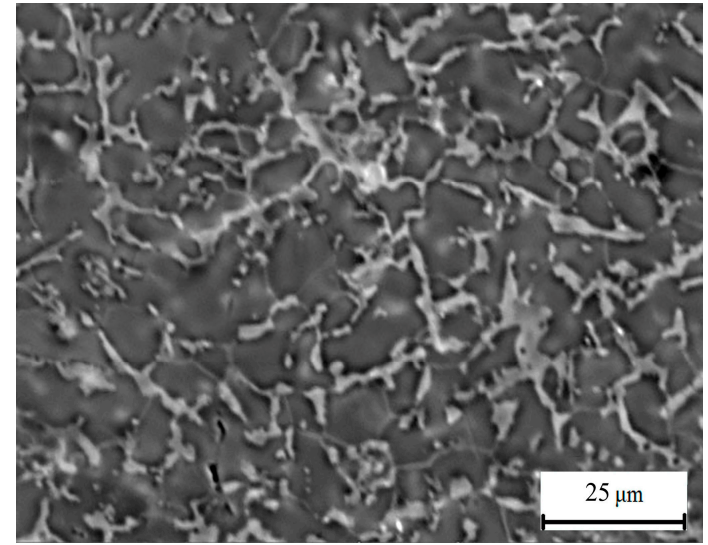

(b)

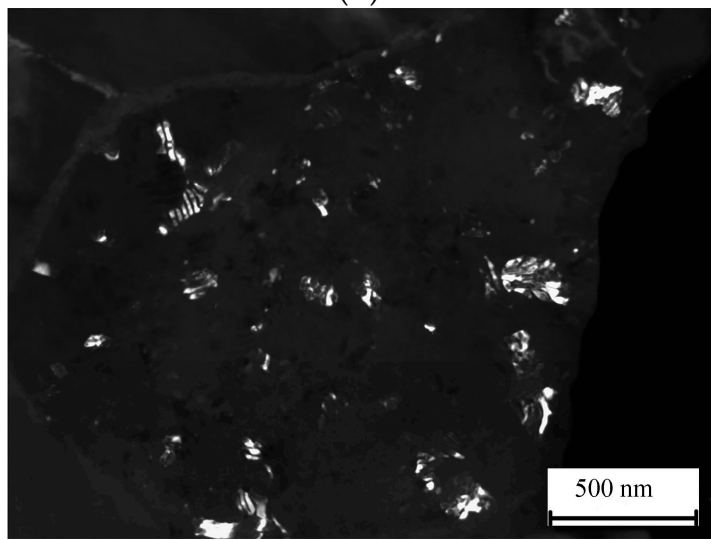

(d)

Figure 8. Microstructure of alloy Al10Mg3Ca1Si. (a) OM, (b) SEM, (c,d) transmission electron microscope (TEM): (a) as-cast; (b-d) solution treatment at $440{ }^{\circ} \mathrm{C}, 3 \mathrm{~h}$; water quenching and aging at $200{ }^{\circ} \mathrm{C}, 3 \mathrm{~h}$, (c) bright field, (d) dark field $\left(\mathrm{Al}_{3} \mathrm{Mg}_{2}\right)$.

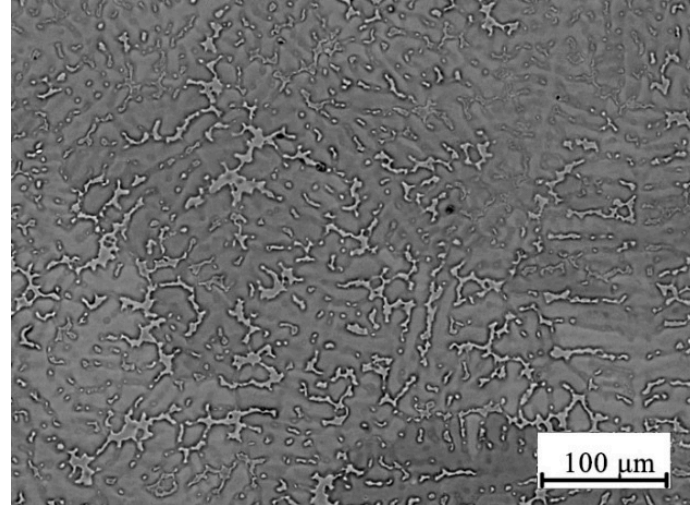

(a)

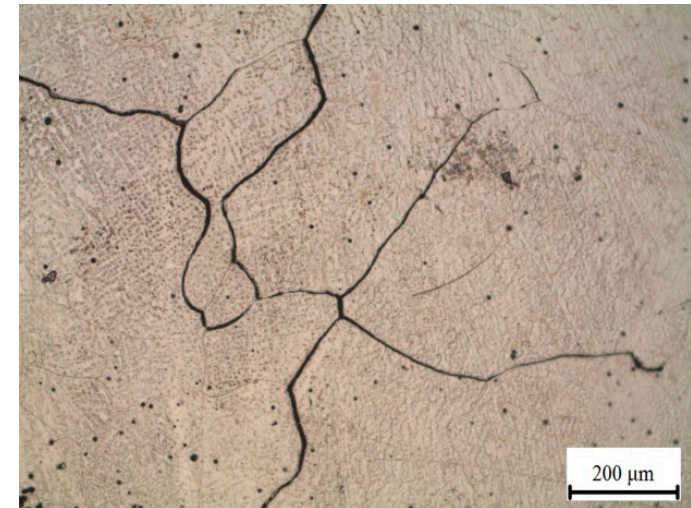

(b)

Figure 9. Microstructure of reference alloy Al10Mg: (a) as-cast, SEM (b) solution treatment at $440{ }^{\circ} \mathrm{C}$, $3 \mathrm{~h}$, water quenching and aging at $200^{\circ} \mathrm{C}, 3 \mathrm{~h}, \mathrm{OM}$.

To experimentally determine the phase transformation temperatures, we conducted a DSC analysis of the experimental alloys (Figure 10). We found that the non-equilibrium solidus that corresponds to the reaction $\mathrm{L} \rightarrow(\mathrm{Al})+\mathrm{Al}_{4} \mathrm{Ca}+\mathrm{Mg}_{2} \mathrm{Si}+\mathrm{Al}_{3} \mathrm{Mg}_{2}$ is at about $450{ }^{\circ} \mathrm{C}$. This temperature is very close to the calculated values (Table 4 ). The experimentally determined temperatures of the equilibrium solidus and liquidus are also fairly close to the calculated values. In particular, in the most 
alloyed Al10Mg10Ca2Si alloy, they are $730{ }^{\circ} \mathrm{C}$ and $500{ }^{\circ} \mathrm{C}$, respectively. The presence of the $\mathrm{Al}_{4} \mathrm{Ca}$ compound in all Ca-containing alloys is confirmed by XRD data. This is illustrated, for example, by the X-ray diffraction patterns of the Al10Mg10Ca2Si and Al10Mg4Ca2Si hypereutectic alloys (Figure 11) in which this compound dominates (Table 1).

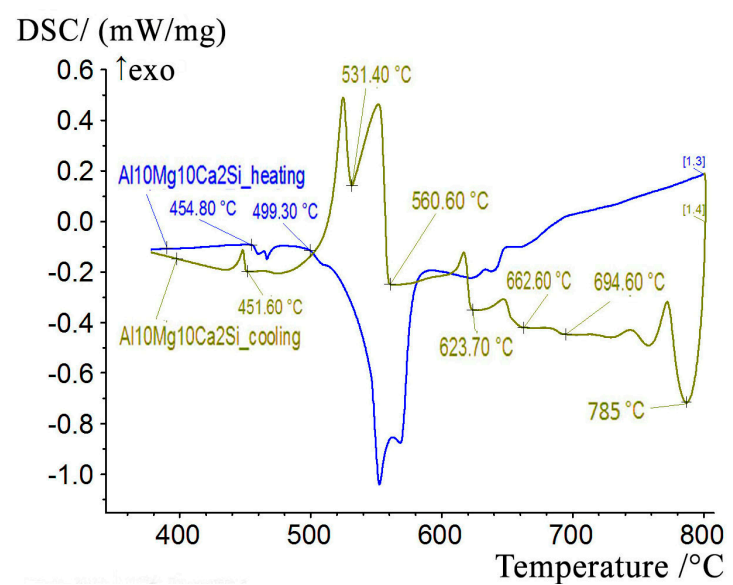

(a)

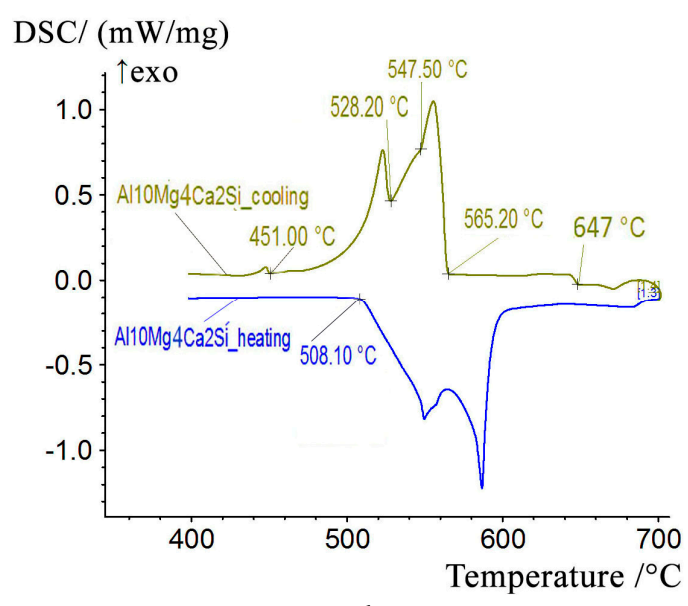

(b)

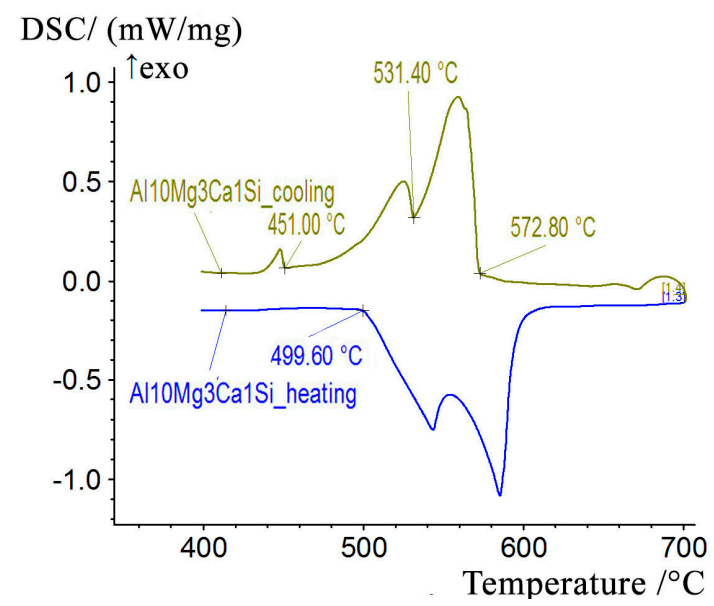

(c)

Figure 10. DSC heating and cooling curves for the quaternary alloys: (a) Al10Mg10Ca2Si (b) Al10Mg4Ca2Si (c) Al10Mg3Ca1Si.

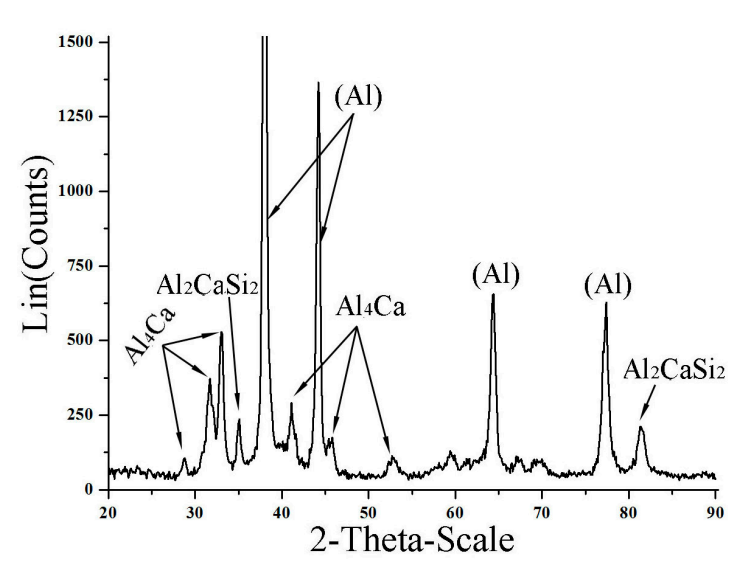

(a)

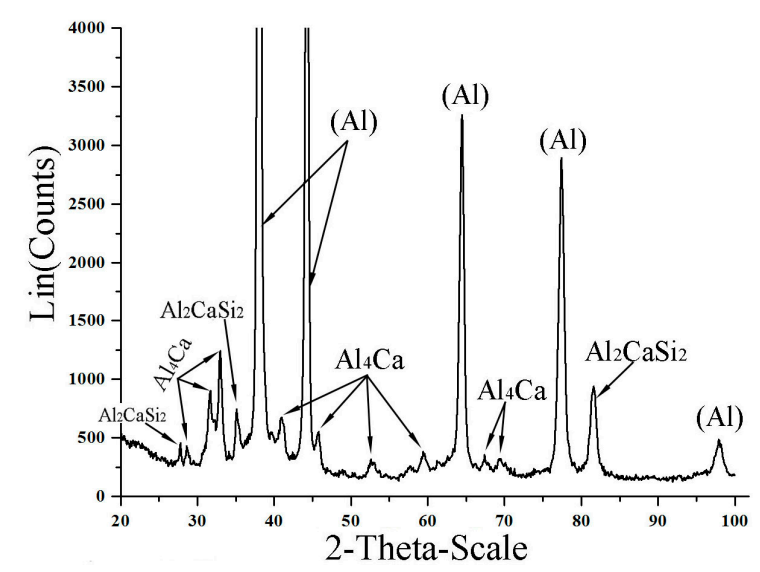

(b)

Figure 11. XRD patterns for the alloys Al10Mg10Ca2Si (a) and Al10Mg4Ca2Si (b). 
The determination of the density of the alloys shows that in all of the alloys with $\mathrm{Ca}$ and $\mathrm{Si}$ additives, it is less than that of the base binary alloy (Table 6). According to the corrosion resistance data, these additives do not have an adverse effect, as no weight loss or change in appearance was detected. The hardness of the as-quenched alloys (Table 6) is determined by the composition of the magnesium containing a supersaturated aluminum solid solution, and the fraction of eutectic phases (Table 1). The hardness of the Ca- and Si-containing alloys is much greater than that of the base alloy, due to the high percentage of the eutectic intermetallic phases. The presence of a significant amount of eutectic particles of Ca- and Si-containing phases suggests the possibility of increasing such characteristics that cannot be achieved in 520 type alloys. In particular, in the eutectic Al10Mg3Ca1Si alloy, the total amount of such phases is about $15 \mathrm{vol} \%$ (Table 1). In the Al10Mg10Ca2Si alloy where the percentage of the second phases is the highest and the density is the lowest (Table 6), the high brittle tendency should be expected due to a large number of primary crystals (Figure 6a).

Table 6. Properties of experimental alloys ${ }^{5}$.

\begin{tabular}{|c|c|c|c|c|c|c|}
\hline Alloy & Density, $\mathrm{g} / \mathrm{cm}^{3}$ & $\Delta m, \%$ & $\mathrm{HB}^{6}$ & $T_{\mathrm{L}},{ }^{\circ} \mathrm{C}$ & $T_{\mathrm{S}},{ }^{\circ} \mathrm{C}$ & $T_{\mathrm{NS}},{ }^{\circ} \mathrm{C}$ \\
\hline $\mathrm{Al12Mg4Ca}$ & 2.53 & 0.075 & 131 & - & - & - \\
\hline $\mathrm{Al} 2.5 \mathrm{Mg} 6 \mathrm{Ca}$ & 2.48 & 0.022 & 79 & - & - & - \\
\hline Al10Mg10Ca2Si & 2.24 & - & 150 & 785 & 499 & 450 \\
\hline $\mathrm{Al} 10 \mathrm{Mg} 4 \mathrm{Ca} 2 \mathrm{Si}$ & 2.33 & - & 117 & 647 & 508 & 451 \\
\hline Al10Mg3Ca1Si & 2.52 & $<0.001$ & 119 & 573 & 500 & 451 \\
\hline Al10Mg & 2.54 & 0.062 & 97 & 607 & 511 & 451 \\
\hline
\end{tabular}

The manufacturability of the experimental Al10Mg3Ca1Si alloy was evaluated in comparison with the base alloy Al10Mg. Grade alloys of the $5 x x$ series have low casting properties due to a broad solidification range. The addition of silicon and calcium reduces this range and promises an increase in the casting properties. The high volume fraction of the brittle phases indicates low manufacturability for pressure treatment. Indeed, the deformability of the Al10Mg3Ca1Si alloy was not high. On the other hand, the $\mathrm{Al} 2.5 \mathrm{Mg} 6 \mathrm{Ca}$ alloy where the $\mathrm{Al}_{4} \mathrm{Ca}$ phase fraction is about $20 \mathrm{vol} \%$ showed sufficiently good manufacturability for hot and cold rolling. It can therefore be concluded that the eutectic inclusions of the Ca-containing phase are sufficient for achieving good processability.

Summarizing the results, we can assume that the A-Ca-Mg-Si system (in particular, the region near the Al10Mg3Ca1Si alloy) is quite suitable as a basis for the development of light corrosion resistant alloys with a «eutectic composite» type structure.

\section{Conclusions}

(1) Using the calculation in the Thermo-Calc program, phase transformations in the Al-Ca-Mg-Si system in the region of aluminum-magnesium alloys have been studied. The structure of this quaternary system has been represented in the form of a polythermal projection (see Figure 1). The following phases can be in equilibrium with the aluminum solid solution: $\mathrm{Al}_{4} \mathrm{Ca}, \mathrm{Mg}_{2} \mathrm{Si}$, $\mathrm{Al}_{3} \mathrm{Mg}_{2}$, and $\mathrm{Al}_{2} \mathrm{CaSi}_{2}$.

(2) In this quaternary system, three five-phase nonvariant reactions can occur: two eutectic, and one peritectic (see Table 3).

(3) We show that the addition of calcium and silicon to the $\mathrm{Al}-10 \% \mathrm{Mg}$ alloy can lead to the formation of primary crystals of the following phases: $\mathrm{Al}_{2} \mathrm{CaSi}_{2}, \mathrm{Al}_{4} \mathrm{Ca}$, and $\mathrm{Mg}_{2} \mathrm{Si}$. The formation of the ternary compound is most probable in this case.

(4) In all the alloys considered, the solidification ends with the nonvariant eutectic reaction $\mathrm{L} \rightarrow$ (Al) $+\mathrm{Al}_{4} \mathrm{Ca}+\mathrm{Mg}_{2} \mathrm{Si}+\mathrm{Al}_{3} \mathrm{Mg}_{20}$, the temperature and liquid phase composition of which are close to those of the reaction for the Al-Mg binary system. 
(5) It is established that the addition of Ca and $\mathrm{Si}$ in the Al-based alloy of $10 \% \mathrm{Mg}$ increases hardness, reduces the density, and has no negative influence on the corrosion resistance.

Acknowledgments: The authors wish to acknowledge the financial support from the Ministry of Education and Science of the Russian Federation (Project No 11.7172.2017/8.9).

Author Contributions: Belov Nikolay Alexandrovich conceived and designed the experiments, conducted thermodynamic calculations, analyzed the results, wrote the paper (general edition); Naumova Evgenia Alexandrovna designed and performed the experiments, analyzed the results, wrote the part of the paper; Akopyan Torgom Karyoevich carried out of a part of thermodynamic calculations, performed the experiments, analyzed the results, wrote the part of the paper; Doroshenko Vitaliy Vladimirovich prepared samples and tools for experiments, performed the experiments, analyzed the results.

Conflicts of Interest: The authors declare no conflict of interest.

\section{References}

1. Kaufman, J.G.; Rooy, E.L. Aluminum Alloy Castings: Properties, Processes, and Applications; ASM International: Materials Park, OH, USA, 2004; p. 340. ISBN 0-87170-803-5.

2. Hatch, J.E. (Ed.) Aluminum: Properties and Physical Metallurgy; ASM International: Materials Park, OH, USA, 1984; p. 396, ISBN-13:978-0871701763.

3. Zolotorevskiy, V.S.; Belov, N.A.; Glazoff, M.V. Casting Aluminum Alloys; Elsevier: Amsterdam, The Netherlands, 2007; p. 530, ISBN-10 0080453708.

4. Mondolfo, L.F. Aluminium Alloys: Structure and Properties; Butterworths: London, UK; Boston, MA, USA, 1976; p. 971. ISBN 0-408-70680-5 16.10.

5. Nagaumi, H.; Suvanchai, P.; Okane, T.; Umeda, T. Mechanical properties of high strength Al-Mg-Si alloy during solidification. Mater. Trans. 2006, 47, 2918-2924. [CrossRef]

6. Ji, S.; Watson, D.; Fan, Z.; White, M. Development of a super ductile die cast Al-Mg-Si alloy. Mater. Sci. Eng. 2012, 556, 824-833. [CrossRef]

7. Ji, S.; Yang, W.; Gao, F.; Watson, D.; Fan, Z. Effect of iron on the microstructure and mechanical property of Al-Mg-Si-Mn and Al-Mg-Si die cast alloys. Mater. Sci. Eng. 2013, 564, 130-139. [CrossRef]

8. Fatemi-Jahromi, F.; Emamy, M. An investigation into high temperature tensile behavior of hot-extruded Al-15 wt \% Mg ${ }_{2} \mathrm{Si}$, composite with Cu-P addition. Manuf. Sci. Technol. 2015, 3, 160-169.

9. Wang, E.; Liu, F.; Chen, L.; Zha, M.; Liu, G.; Jiang, Q. The effect of Sb addition on microstructures and tensile properties of extruded Al-20Mg 2 Si-4Cu alloy. Mater. Sci. Eng. A 2016, 657, 331-338. [CrossRef]

10. Emamy, M.; Emami, A.R.; Tavighi, K. The effect of $\mathrm{Cu}$ addition and solution heat treatment on the microstructure, hardness and tensile properties of $\mathrm{Al}-15 \% \mathrm{Mg} 2 \mathrm{Si}-0.15 \% \mathrm{Li}$ composite. Mater. Sci. Eng. A 2013, 576, 36-44. [CrossRef]

11. Nordin, N.A.; Farahany, S.; Ourdjini, A.; Abu Bakar, T.; Hamzah, E. Refinement of $\mathrm{Mg}_{2} \mathrm{Si}$ reinforcement in a commercial $\mathrm{Al}-20 \% \mathrm{Mg} 2 \mathrm{Si}$ in-situ composite with bismuth, antimony and strontium. Mater. Charact. 2013, 86, 97-107. [CrossRef]

12. Ren, B.; Liu, Z.-X.; Zhao, R.-F.; Zhang, T.-Q.; Liu, Z.-Y.; Wang, M.-X.; Weng, Y.-G. Effect of Sb on microstructure and mechanical properties of $\mathrm{Mg}_{2} \mathrm{Si} / \mathrm{Al}-\mathrm{Si}$ composites. Trans. Nonferr. Met. Soc. China 2010, 20, 1367-1373. [CrossRef]

13. Zhang, J.; Fan, Z.; Wang, Y.Q.; Zhou, B.L. Microstructural development of Al- $15 \mathrm{wt} \% \mathrm{Mg}_{2} \mathrm{Si}$ in-situ composite with michmetal addition. Mater. Sci. Eng. A 2000, 281, 104-112. [CrossRef]

14. Kim, W.J.; Lee, Y.G. High-strength Mg-Al-Ca alloy with ultrafine grain size sensitive to strain rate. Mater. Sci. Eng. 2011, 528, 2062-2066. [CrossRef]

15. Aljarrah, M.; Medraj, M.; Wang, X.; Essadiqi, E.; Muntasar, A.; Dénès, G. Experimental investigation of the Mg-Al-Ca system. J. Alloys Compd. 2007, 436, 131-141. [CrossRef]

16. Janz, A.; Gröbner, J.; Cao, H.; Zhu, J.; Chang, Y.A.; Schmid-Fetzer, R. Thermodynamic modeling of the Mg-Al-Ca system. Acta Mater. 2009, 57, 682-694. [CrossRef]

17. Xu, S.W.; Oh-ishi, K.; Kamado, S.; Uchida, F.; Homma, T.; Hono, K. High-strength extruded Mg-Al-Ca-Mn alloy. Scr. Mater. 2011, 65, 269-272. [CrossRef]

18. Pekguleryuz, M. Creep Resistance in Mg-Al-Ca Casting Alloys; The Minerals Metals \& Materials Society (TMS): Pittsburgh, PA, USA, 2000; pp. 12-17. 
19. Gröbner, J.; Kevorkov, D.; Chumak, I.; Schmid-Fetzer, R. Experimental and thermodynamic calculation of ternary Mg-Al-Ca phase equilibria. Z. Metallkd. 2003, 94, 976-982. [CrossRef]

20. Chino, Y.; Kobata, M.; Iwasaki, H.; Mabuchi, M. Tensile properties from room temperature to $673 \mathrm{~K} \mathrm{of} \mathrm{Mg-0.9}$ mass \% Ca alloy containing lamella $\mathrm{Mg}_{2}$ Ca. Mater. Trans. 2002, 43, 2643-2646. [CrossRef]

21. Liang, S.M.; Chen, R.S.; Blandin, J.J.; Suery, M. Thermal analysis and solidification pathways of Mg-Al-Ca system alloys. Mater. Sci. Eng. 2008, 480, 365-372. [CrossRef]

22. Ninomiya, R.; Ojiro, T.; Kubota, K. Improved heat resistance of Mg-Al alloys by the Ca addition. Acta Metall. Mater. 1995, 43, 669-674. [CrossRef]

23. Li, P.; Tang, B.; Kandalova, E.G. Microstructure and properties of AZ91D alloy with Ca additions. Mater. Lett. 2005, 59, 671-675. [CrossRef]

24. Wasiur-Rahman, S.; Medraj, M. Critical assessment and thermodynamic modeling of the binary Mg-Zn, Ca-Zn and ternary Mg-Ca-Zn systems. Intermetallics 2009, 17, 847-864. [CrossRef]

25. Mondal, D.P.; Jha, N.; Badkul, A.; Das, S.; Yadav, M.S.; Jain, P. Effect of calcium addition on the microstructure and compressive deformation behaviour of 7178 aluminium alloy. Mater. Des. 2011, 32, 2803-2812. [CrossRef]

26. Ludwig, T.H.; Schonhovd Dashlen, E.; Schaffer, P.L.; Arnberg, L. The effect of Ca and P interaction on the Al-Si eutectic in a hypoeutectic Al-Si alloy. J. Alloys Compd. 2014, 586, 180-190. [CrossRef]

27. Perez-Prado, M.T.; Cristina, M.C.; Ruano, O.A.; Gonza, G. Microstructural evolution of annealed Al-5\% Ca-5\% Zn sheet alloy. J. Mater. Sci. 1997, 32, 1313-1318. [CrossRef]

28. Kevorkov, D.; Schmid-Fetzer, R. The Al-Ca System, Part 1: Experimental investigation of phase equilibria and crystal structures. Z. Metallkd. 2001, 92, 946-952.

29. Ozturk, K.; Chen, L.Q.; Liu, Z.K. Thermodynamic assessment of the Al-Ca binary system using random solution and associate models. J. Alloys Compd. 2002, 340, 199-206. [CrossRef]

30. Belov, N.A.; Naumova, E.A.; Alabin, A.N.; Matveeva, I.A. Effect of scandium on structure and hardening of Al-Ca eutectic alloys. J. Alloys Compd. 2015, 646, 741-747. [CrossRef]

31. Belov, N.A.; Naumova, E.A.; Bazlova, T.A.; Alekseeva, E.V. Structure, phase composition, and strengthening of cast Al-Ca-Mg-Sc alloys. Phys. Met. Metallogr. 2016, 117, 199-205. [CrossRef]

32. Petzow, G.; Effenberg, G. Ternary Alloys: A Comprehensive Compendium of Evaluated Constitutional Data and Phase Diagrams; Verlagsgesellschaft: Weinheim, Germany, 1990; Volume 3, p. 614.

33. Reference Data for Thermodynamic Calculations. Available online: http:/ /www.thermocalc.com (accessed on 5 July 2017).

34. Belov, N.; Naumova, E.; Akopyan, T. Effect of $0.3 \mathrm{wt} \%$ Sc on structure, phase composition and hardening of Al-Ca-Si eutectic alloys. Trans. Nonferr. Met. Soc. China 2017, 27, 741-746. [CrossRef]

35. Belov, N.A.; Eskin, D.G.; Aksenov, A.A. Multicomponent Phase Diagrams: Applications for Commercial Aluminium Alloys; Elsevier: Amsterdam, The Netherlands, 2005; p. 424. ISBN 9780080445373.

36. Ghidelli, M.; Gravier, S.; Blandin, J.-J.; Pardoen, T.; Raskin, J.-P.; Mompiou, F. Compositional-induced structural change in $\mathrm{Zr}_{x} \mathrm{Ni}_{100-x}$ thin film metallic glasses. J. Alloys Compd. 2014, 615, S348-S351. [CrossRef]

37. Louzguine-Luzgin, D.V.; Inoue, A. Structure and transformation behaviour of a rapidly solidified Al-Y-Ni-Co-Pd alloy. J. Alloys Compd. 2005, 399, 78-85. [CrossRef]

38. Yi, J.J.; Xiong, X.Z.; Inoue, A.; Konga, L.T.; Lia, J.F. Glass forming ability of Al-Ni-La alloys with Si addition. J. Alloys Compd. 2015, 650, 578-583. [CrossRef]

39. Backerud, L.; Krol, E.; Tamminen, J. Solidification Characteristics of Aluminium Alloys; Tangen Trykk A/S: Oslo, Norway, 1982; p. 152.

40. Prasad, S.D.; Krishna, R.A. Production and mechanical properties of A356.2/RHA composites. Int. J. Adv. Manuf. Technol. Sci. 2011, 33, 51-58.

41. Mizuuchi, K.; Takeuchi, T.; Fukusumi, M.; Sugioka, M.; Nagai, H. Effect of processing condition on the properties of $\mathrm{Al} / \mathrm{Al} 3 \mathrm{Ti}$ composites produced by LCCS process. J. Jpn. Inst. Met. 1998, 62, 893-898. [CrossRef]

42. Tham, L.M.; Gupta, M.; Cheng, L. Effect of limited matrix-reinforcement interfacial reactions on enhancing the mechanical properties of aluminum-silicon carbide composites. Acta Mater. 2001, 49, 3243-3253. [CrossRef]

(C) 2017 by the authors. Licensee MDPI, Basel, Switzerland. This article is an open access article distributed under the terms and conditions of the Creative Commons Attribution (CC BY) license (http://creativecommons.org/licenses/by/4.0/). 